\title{
Reconstruction of human subsistence and husbandry strategies from the Iberian Early Neolithic: A stable isotope approach
}

\author{
Vanessa Villalba-Mouco ${ }^{1}$ @ | Pilar Utrilla ${ }^{1}$ | Rafael Laborda ${ }^{1}$ | José Ignacio Lorenzo ${ }^{1}$ | \\ Cristina Martínez-Labarga ${ }^{2}$ ๑ | Domingo C. Salazar-García ${ }^{3,4}$
}

${ }^{1}$ Departamento de Ciencias de la Antigüedad, Grupo Primeros Pobladores del Valle del Ebro (PPVE), Instituto de Investigación en Ciencias Ambientales (IUCA), Universidad de Zaragoza, Pedro Cerbuna 12, Zaragoza 50009, Spain

${ }^{2}$ Centro di Antropologia molecolare per lo studio del DNA antico Dipartimento di Biologia, Università degli Studi di Roma "Tor Vergata" Via della Ricerca Scientifica 1, Roma 00173, Italia

${ }^{3}$ Departamento de Geografía, Prehistoria y Arqueología, Grupo de Investigación en Prehistoria IT-622-13 (UPV-EHU)/ IKERBASQUE-Basque Foundation for Science, Vitoria, Spain

${ }^{4}$ Department of Geological Sciences, University of Cape Town, Cape Town, South Africa

\section{Correspondence}

Vanessa Villalba-Mouco, Departamento de Ciencias de la Antigüedad, Universidad de Zaragoza, Pedro Cerbuna 12, 50009, Zaragoza, Spain.

Email:vvmouco@unizar.es

and

Domingo C. Salazar-García, Departamento de Geografía, Prehistoria y Arqueología, Universidad del País Vasco-Euskal Herriko Unibertsitatea, C/Francisco Tomás y Valiente s/n. 01006, Vitoria-Gasteiz, Spain.

Email: domingocarlos.salazar@ehu.eus

Funding information

Fundación Ibercaja-CAI (2016); Research Stay Scholarship; Gobierno de Aragón and the Fondo Social Europeo; Predoctoral Scholarship, Grant/Award Number: BOA20150701025; Transiciones Climáticas y Adaptaciones Sociales en la Prehistoria de la Cuenca del Ebro, Grant/Award Number: HAR2014-59042-P; PPVE research group (H07: Primeros Pobladores del Valle del Ebro); BBVA Foundation; I Ayudas a Investigadores, Innovadores y Creadores Culturales

\begin{abstract}
Objectives: The Early Neolithic involved an important social and economic shift that can be tested not only with the material culture, but also through biomolecular approaches. The Iberian Peninsula presents few Early Neolithic sites where fauna and humans can be analyzed together from an isotopic perspective. Here we present an isotopic study on the site of Cueva de Chaves as an example for understanding the dietary and economical changes that took place during Early Neolithic in Iberia.

Material and methods: Here we apply carbon and nitrogen stable isotope analysis to bone collagen from 4 humans and 64 faunal samples from 14 different species. The large dataset belongs to the same unique chrono-cultural context secured by 20 radiocarbon dates. Three direct new radiocarbon dates were carried out on the human remains analyzed.

Results: Faunal isotope values show no significant differences between wild and domestic herbivores, although the latter have more homogeneous values. Domestic pigs, potentially considered omnivorous, also show signatures of a herbivore diet. Human isotopic results show a diet mainly based on terrestrial $C_{3}$ resources and possibly high meat consumption. The only individual found buried with a special funerary treatment presents a slightly different protein intake, when taking into account the long contemporaneous baseline analyzed.

Discussion: Similar values between wild and domestic species could be the result of common feeding resources and/or grazing on the same parts of the landscape. The herbivore diet seen amongst domestic pigs rules out feeding on household leftovers. High meat consumption by humans would support the hypothesis of the existence of a specialized animal husbandry management community in which agriculture was not intensively developed. Our results suggest that the development of agricultural practices and animal husbandry were not necessarily associated together in the early stages of the Western Mediterranean Neolithic.
\end{abstract}

\section{KEYWORDS}

animal management, cardial, carbon and nitrogen stable isotopes, funerary practices, domestication, radiocarbon dating

\section{INTRODUCTION}

The rise of the Neolithic involved important cultural, economic, genetic and environmental changes in many places, including the Western
Mediterranean (Salazar-García and García-Puchol, 2017a). These changes are relatively easy to prove throughout the archaeological record. The so-called Neolithic package normally includes an increase of material culture including first pottery and polished stone, and then 


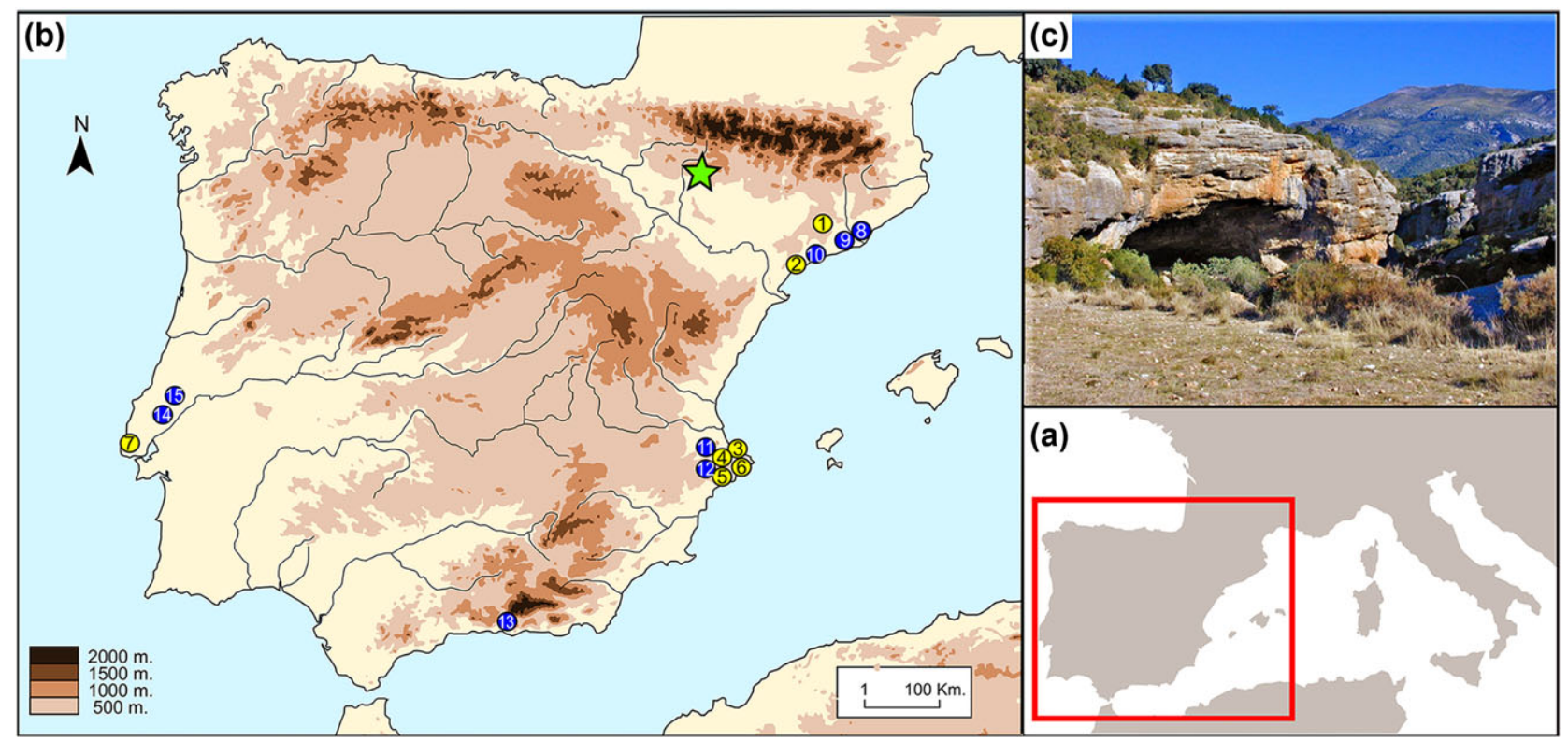

FIGURE 1 Location map. (a) Location of the Iberian Peninsula inside Western Europe; (b) Map of the Iberian Peninsula with the Earliest Cardial Neolithic sites but without human remains from this chronology (yellow dots: 1: Guixeres de Vilobí; 2: Cavet; 3: Barranquet; 4: Cova d'en Pardo; 5: Mas d'Is; 6: Cova de les Cendres; 7: Lapia das Lameiras) and sites with Cardial human remains directly dated (blue dots: 8: Plaça de la Vila de Madrid; 9: Cova Bonica; 10: Cova Foradada; 11: Cova de l'Or; 12: Cova de la Sarsa; 13: Cueva de Nerja; 14: Galeria da Cisterna and 15: Gruta do Caldeirão.) The star shows the location of Cueva de Chaves (c) Cueva de Chaves [Color figure can be viewed at wileyonlinelibrary.com]

domestication of animals and cereals (Edwards et al., 2007; Guilaine and Manen, 2007; Zapata, Peña-Chocarro, Pérez-Jordá, \& Stika, 2004; Zilhão, 2001).

Different types of studies have shown the Fertile Crescent as the origin of the Neolithic cultures that spread throughout Europe and northern Africa (Lemmen, Gronenborn, \& Wirtz, 2011; Zeder, 2008). The demographic expansion spread towards the Balkan Peninsula, where the Neolithic is then genetically and culturally differentiated into two population groups (Fernández et al., 2014; Olalde et al., 2015). One of these groups followed the Danube river and resulted in the LBK ware culture (Linearbandkeramik), which eventually spread throughout Central Europe between 5500 and 4900 cal BC (Manning et al., 2014). The other group spread faster through Western Europe by the Mediterranean coast and led to the Impressa ware culture (between 5800 and 5400 cal BC), and the Cardial ware culture (between 5500 and 4900 cal BC) (Binder and Sénépart, 2010). The Cardial expansion seemed to reach the Iberian Peninsula first (Gamba et al., 2012), although the presence of some vestiges of Impressa ware has been suggested at some coastal sites (Bernabeu, Molina, Esquembre, Ortega, Boronat, 2009). In any case, it is clear that the arrival of farming practices to Iberia arrived mainly through maritime colonization (Isern, Zilhão, Fort, \& Ammerman, 2017; Zilhão, 2001). This maritime pioneering is in agreement with the fact that the first Neolithic sites are situated in the coastal region and have Cardial pottery (Bernabeu, García-Puchol, \& Orozco-Köhler, 2018), whereas inland Early Neolithic sites occur later and show no Cardial pottery (Rojo-Guerra, Kunst, Garrido-Pena, \& García-Martínez de Lagrán, 2006).

\subsection{Cueva de Chaves and its importance in the neolithization of Iberia}

Cueva de Chaves is a cave located in the northeast of Iberia, at $663 \mathrm{~m}$. a.s.l. (metres above sea level) in the Prepyrenean mountain range of Sierra de Guara (Bastarás, Huesca, Aragón; UTM: 735325.00 X; 4678636.00 Y; ETRS 89, Datum 30) (Figure 1). The site was excavated between 1984 and 2007 under the direction of Pilar Utrilla (Paleolithic levels) and Vicente Baldellou (Neolithic levels). The cave has about $225 \mathrm{~m}$ of extension, of which $110 \mathrm{~m}$ were potentially inhabitable (Baldellou, 2012). Cueva de Chaves was occupied during the Paleolithic (Solutrean and Magdalenian), Neolithic and, sporadically, the Bronze Age and Late Roman periods. Neolithic deposits from levels la and Ib date to the Early Neolithic period (la 5600-5300 cal BC; lb 5300-5000 cal $\mathrm{BC}$ ). These two chronologically consecutive levels have in them domestic fauna (Castaños, 2004), Cardial pottery (Baldellou, 2012; Utrilla and Laborda, 2018) and schematic rock art painted on pebbles (Utrilla and Baldellou, 2002, 2007) (Figure 2, Table 1).

Cueva de Chaves represents an interesting case study, as it is located inland but its radiocarbon dates show the use of the cave mostly as a settlement during the early stages of the Neolithic colonization of Iberia, overlapping with short-life radiocarbon dates from other nearby Cardial coastal Early Neolithic sites such as Guixeres de Vilobí, El Cavet (Martins et al., 2015), Cova de les Cendres, Cova d'En Pardo, Barranquet, Mas D'ls (Bernabeu et al., 2009), Cueva de Nerja (García-Borja, Aura Tortosa, Jordá Pardo, \& Salazar García, 2014), Caldeirão (Zilhão, 1992), Galería da Cisterna-Almolda (Martins et al., 2015; Zilhão, 2001) and Lapias das Lameiras (Davis and Simões, 2016). Moreover, only few sites in Iberia have human remains recovered from Cardial levels that have been directly dated: Caldeirão 


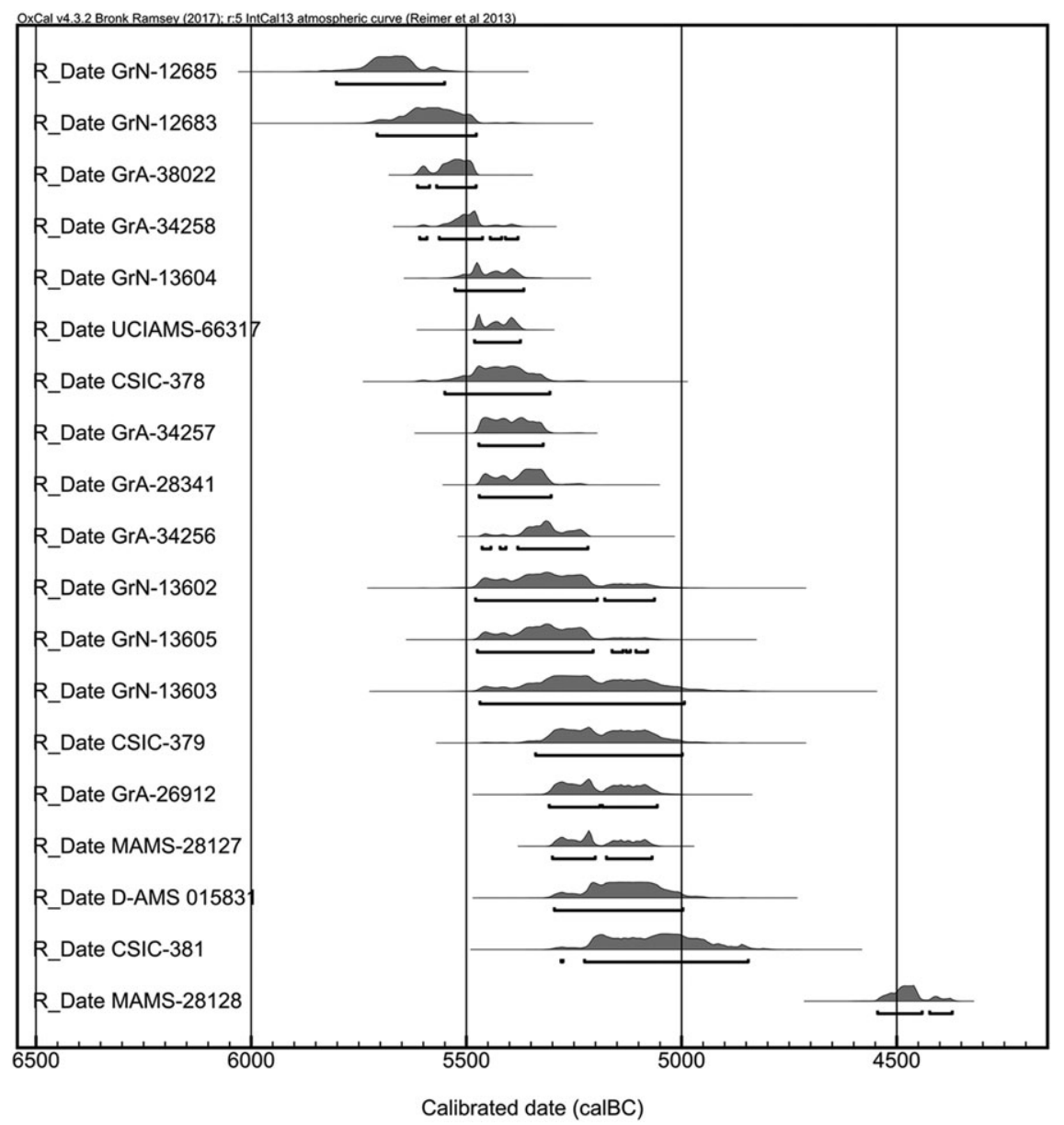

FIGURE 2 AMS radiocarbon dates from Cueva de Chaves. All dates have been calibrated with OxCal v4.2.3 and using the IntCal13 calibration curve (Bronk Ramsey, 2009; Reimer et al., 2013)

TABLE 1 AMS radiocarbon dates from the Early Neolithic levels of Cueva de Chaves, calibrated with OxCal v4.2.3 using the IntCal13 calibration curve (Bronk Ramsey, 2009; Reimer et al., 2013)

\begin{tabular}{|c|c|c|c|c|c|}
\hline Lab code & Sample & ${ }^{14} \mathrm{C}$ age & $1 \sigma \mathrm{Cal} B C$ & $2 \sigma \mathrm{Cal} B C$ & Reference \\
\hline GrN-12685 & charcoal & $6770 \pm 70$ & $5723-5627$ & $5799-5550$ & Baldellou, 2012 \\
\hline GrN-12683 & charcoal & $6650 \pm 80$ & $5634-5515$ & $5707-5478$ & Baldellou, 2012 \\
\hline GrA-34258 & charcoal & $6530 \pm 40$ & $5528-5473$ & $5609-5380$ & Baldellou, 2012 \\
\hline GrN-13604 & charcoal & $6490 \pm 40$ & $5487-5379$ & $5527-5368$ & Baldellou, 2012 \\
\hline UCIAMS-66317 & Ovis aries & $6470 \pm 25$ & $5479-5382$ & $5481-5374$ & Baldellou, 2012 \\
\hline GrA-34257 & charcoal & $6410 \pm 40$ & $5468-5357$ & $5471-5322$ & Baldellou, 2012 \\
\hline GrA-28341 & acorn & $6380 \pm 40$ & $5464-5315$ & $5471-5303$ & Baldellou, 2012 \\
\hline GrA-34256 & charcoal & $6335 \pm 40$ & $5367-5295$ & $5464-5218$ & Baldellou, 2012 \\
\hline GrN-13602 & charcoal & $6330 \pm 90$ & $5465-5216$ & $5478-5063$ & Baldellou, 2012 \\
\hline GrN-13605 & charcoal & $6330 \pm 70$ & $5374-5219$ & $5474-5079$ & Baldellou, 2012 \\
\hline MAMS 29127 & human & $6227 \pm 28$ & $5292-5081$ & $5299-5070$ & This article \\
\hline D-AMS 015831 & human & $6180 \pm 54$ & $5213-5057$ & $5296-4998$ & This article \\
\hline CSIC-381 & charcoal & $6120 \pm 70$ & $5207-4963$ & $5281-4845$ & Baldellou, 2012 \\
\hline MAMS 28128 & human & $5645 \pm 31$ & $4518-4452$ & $4544-4373$ & This article \\
\hline
\end{tabular}




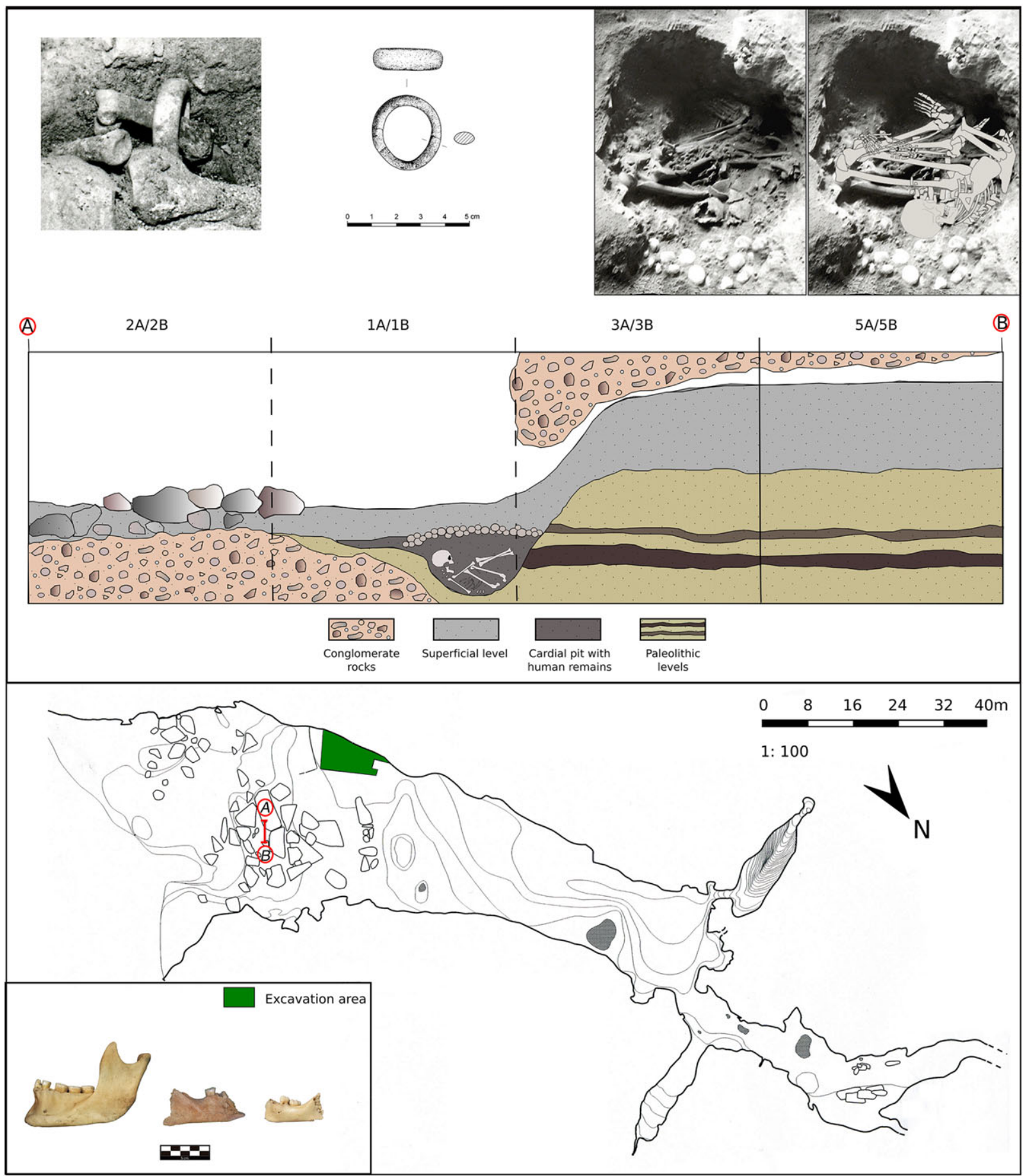

FIGURE 3 Early Neolithic human remains from Cueva de Chaves and their position in the topography. (a) Early Neolithic human remains sampled and recovered from the excavation area reflected in the topography; (b) Stratigraphic profile in the area where the Cardial burial was found; and (c) Detailed picture of the ring recovered from the Cardial burial and the archaeological drawing detailing the position of the skeleton [Color figure can be viewed at wileyonlinelibrary.com]

(Zilhão, 1992), Galería da Cisterna-Almonda (Martins et al., 2015), Cova de la Sarsa (García-Borja, Salazar-García, Pérez, Pardo, \& Casanova, 2011), Cova de l'Or (Olalde et al., 2015), Cova Foradada (Oms, Cebrià, Morales, \& Pedro, 2015), Vila de Madrid (Pou, Martí, Jordana, Malgosa, \& Gibaja, 2010), Cova Bonica (Oms et al., 2017), Cueva de Nerja (Salazar-García, Pérez-Ripoll, García-Borja, \& Jordá Pardo, 2017b) and now Cueva de Chaves. Of all of these sites, only Cueva de Chaves has an individual in complete anatomical articulation. This individual was buried in a pit with a flexed position, had an associated ring, and was covered by red pigment and pebbles. All these features could be representative of the less well known Cardial funerary rituals (Utrilla, Lorenzo, Baldellou, Sopena, \& Ayuso, 2008) (Figure 3).

Cueva de Chaves was mostly a habitat settlement, although it also had some areas dedicated to funerary practices. Besides the funerary area (Utrilla et al., 2008), evidence of different daily activities typical of a Neolithic community have been discovered inside the cave, shedding light on the broad Neolithic lifestyle: evidence of hunting (Castaños, 2004; Domingo, 2009), butchery and harvest activities 
(Domingo, 2014; López García, 1992; López García and López-Sáez, 2000; Mazzucco, Clemente-Conte, Gassiot, \& Gibaja, 2015), schematic art representations in pebbles, (Utrilla and Baldellou, 2002, 2007), fireplaces and storage structures (Alcolea, Utrilla, Piqué, Laborda, \& Mazo, 2017; Sánchez, 2013). Many of these tasks can be recorded separately, and evidence of most of them together usually happen only in open-air settlements such as La Draga (Bosch, Chinchilla, \& Tarrús, 2011) and Guixeres de Vilobí (Oms, Esteve, Mestres, Martín, \& Martins, 2014a). In this sense, it is considered that Cueva de Chaves is mainly an example of a settlement located inside a cave (Alcolea et al., 2017). Moreover, the environmental conditions of the cave resulted in conservation of its archaeological material, making Cueva de Chaves an essential site to understand the neolithization process of Iberia. Unfortunately, the Neolithic levels were intentionally destroyed in 2007 to build an illegal enclosure for animals of a private hunting ground situated around the cave, so almost nothing is left at the archaeological site (Sentence num. 00255/2016 11/11/16).

\section{2 | Isotopic analysis for dietary and environmental reconstructions}

The use of carbon $\left(\delta^{13} \mathrm{C}\right)$ and nitrogen $\left(\delta^{15} \mathrm{~N}\right)$ stable isotope ratios from bone collagen gives a quantitative assessment of protein consumption (e.g., Lee-Thorp, 2008). Stable isotope analysis of Early Neolithic remains has proved useful to establish the socio-economic impact of farming (e.g., Arias, 2007; Lillie and Richards, 2000; Lubell, Jackes, Schwarcz, Knyf, \& Meiklejohn, 1994; Schulting, 1998). This quantitative dietary approach has been useful in establishing subsistence patterns of the first farmers, as well as shedding light on animal and plant management practises at the time (e.g., Balasse et al., 2014, 2016; Navarrete et al., 2017).

The $\delta^{13} \mathrm{C}$ measurement is suitable to distinguish between protein from marine and terrestrial resources (Schoeninger and De Niro, 1984), as well as proteins from plants with different photosynthetic pathways $\left(C_{3}\right.$ and $\left.C_{4}\right)$ (Van der Merwe, 1982) and different environments (Goude and Fontugne, 2016). Estuarine aquatic resources, commonly consumed in the Western Mediterranean might have lower $\delta^{13} \mathrm{C}$ values than expected (e.g., Salazar-García et al., 2014), so special care should be taken interpreting their consumption in the region. In addition, $\delta^{15} \mathrm{~N}$ values can be used to establish the trophic level a specific organism holds in the food chain of its environment, with an overall agreed estimated increase of 3-5\% per trophic step (Bocherens and Drucker, 2003). Using the same principles, it is also possible to detect domestic species-specific feeding (Navarrete et al., 2017) and manuring practises due to high $\delta^{15} \mathrm{~N}$ values (Bogaard, Heaton, Poulton, \& Merbach, 2007; Bogaard et al., 2013). Analyzing the values of fauna and humans together can offer more information about aspects of the ecology of the first anthropic ecosystems during the onset of the Neolithic. Here we have reconstructed dietary habits and trophic structure of the Early Neolithic ecosystem from Cueva de Chaves.

The main limitation of stable isotope analysis in bone collagen is that it mainly reflects protein consumption, resulting in a considerable amount of animal proteins masking plant food consumption (Hedges and Reynard, 2007). Another aspect to take into consideration is collagen turnover, which is low during adulthood and therefore reflects an average diet of the last years before the individual died (Hedges, Clement, Thomas, \& O'connell, 2007; Hill, 1998). Subadult individuals could still show a breastfeeding or weaning isotopic signal (Herrscher, Goude, \& Metz, 2017), as well as having isotopic values that reflect a narrower window of time before death because of their faster collagen turnover (Valentin, 2002).

\section{2 | MATERIAL AND METHODS}

This study focuses on the Early Neolithic levels la (5600-5300 cal BC) and $\mathrm{lb}$ (5300-5000 cal BC). Both levels are consecutive to each other and show no radiocarbon discontinuity when considering short-life dates (Table 1, Figure 2). New and previous direct human radiocarbon dates overall confirm this. Therefore, materials from both levels have been considered as one common Early Neolithic assemblage, and samples were taken indifferently from both.

\subsection{Human and faunal remains}

Initially, the $\mathrm{MNI}$ (minimum number of individuals) recovered from Cueva de Chaves was 8, based on the number of mandibles. One of the individuals was found in correct anatomical position and buried in a pit. The other seven were found disarticulated and commingled with other archaeological material, some of them in superficial levels (Figure 3). Because of this unclear attribution of the human remains, all skeletal material that defined the MNI (seven mandibles and one rib from the isolated individual) was directly radiocarbon dated. A total of 4 of the individuals were dated to the Early Neolithic period: three adults and one subadult. Three of them (two adults and the subadult) date from the beginning of the Early Neolithic, and one adult individual dates to the end of the Early Neolithic (Table 1, Figure 2). This last individual was included in the isotopic analysis, but the results are to be considered with caution because the date is more recent than those of the remaining individuals. The subadult individual (S-UCT 21023) was estimated to be around 4 years old, according to its dental eruption pattern (Ubelaker, 1989); no other subadult remains were found to help infer more aspects about individual health and lifestyle. Mandible S-UCT 21025 belongs to an adult individual; presenting a robust appearance (pronounced gonion and chin) associated with male traits, a molar wear pattern corresponds with 25-35 years of age (following Brothwell, 1981), and shows neither antemortem dental loss nor caries, although dental calculus is present. Mandible S-UCT 19600 shows a more gracile aspect, although only one fragment of the mandibular body is present and thus makes it impossible to determinate sex. However, the molar wear pattern corresponds to an individual of 25-35 years of age (Brothwell, 1981), as seen in the only tooth present (M1), and antemortem loss is observed by alveolar reabsorption of $\mathrm{P} 2, \mathrm{M} 2$ and $\mathrm{M} 3$ on the right side of the mandible. The individual found in correct anatomical position (S-UCT 21024) was identified as an adult male based on morphology of the innominate (Utrilla et al., 2008), and his pubic symphyseal surface corresponds to Todd's (1920) Phase IX, which corresponds to 44-50 years of age. His mandible also shows a heavy wear, in this case corresponding to $33-45$ years of age 
TABLE 2 NR (number of remains) and MNI (minimum number of individuals) faunal remains by taxa categories from Cueva de Chaves (information extracted from Castaños, 2004)

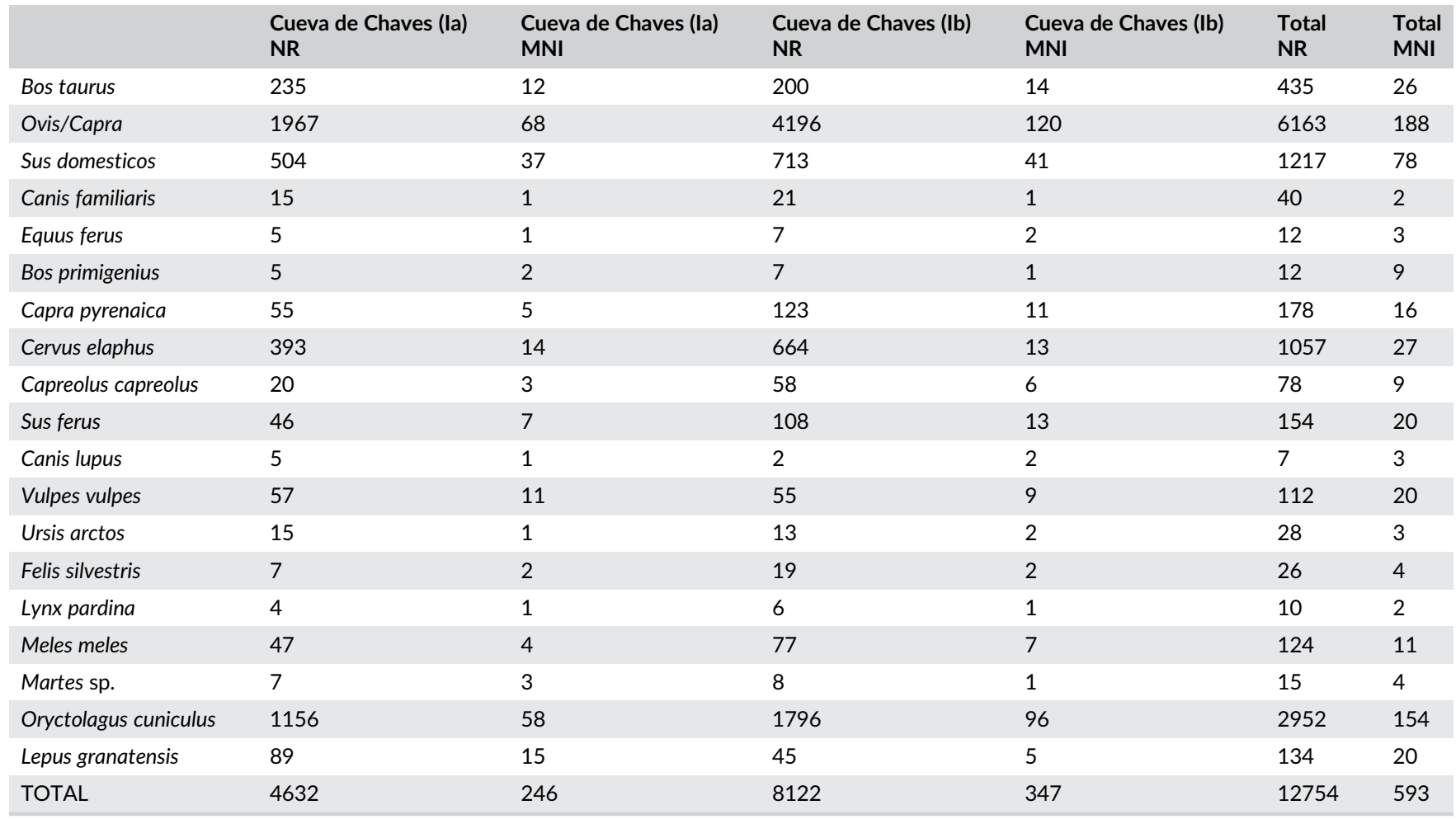

according to Brothwell (1981), and also shows antemortem loss of both third molars as well as caries in one of the second molars and dental calculus on one incisor.

The Neolithic levels from Cueva de Chaves have the highest amount of faunal remains when compared to other Early Neolithic sites from Iberia (Castaños, 2004). Both domestic and wild species recovered from the Early Neolithic levels show an equal percentage of representation: $49.6 \%$ of the total remains are domestic, and $51.4 \%$ are wild (Castaños, 2004) (Table 2). For this study a total of 64 faunal remains of 14 different taxa were selected following the classification of Castaños (2004). The taxa analyzed consists of: Ovis/Capra, Sus domesticus, Bos taurus, Capra pyrenaica, Capreolus capreolus, Equus caballus, Cervus elaphus, Meles meles, Vulpes vulpes, Canis sp., Buteu buteu, Felis silvestris, Oryctolagus cuniculus and Lepus granatensis. Only adult faunal specimens have been sampled in order to avoid altered values due to suckling or weaning effects (Fogel, Tuross, \& Owsley, 1989; Fuller, Fuller, Harris, \& Hedges, 2006). Canis sp. and Felis silvestris are considered as carnivores because of the lack of evidence to define them as either domestic or wild. We have followed Castaños (2004) for determination of domestic or wild Sus specimens, but ruled out subadult specimens, which are impossible to distinguish between domestic and wild, as well as large-sized pig remains following Navarrete and Saña (2017).

\section{2 | Isotopic analysis}

Isotope analysis of the Cueva de Chaves samples was carried out at the Stable Isotope Laboratories of the University of Cape Town (South Africa). A total of 68 samples were cleaned by removing the bone outer layer by mechanical abrasion using a 220 Dremel 3500 drill. Collagen extraction for carbon $\left(\delta^{13} \mathrm{C}\right)$ and nitrogen $\left(\delta^{15} \mathrm{~N}\right)$ isotope analysis was done following the Longin (1971) method with the addition of an ultrafiltration step (Brown, Nelson, Vogel, \& Southon, 1988). Approximately $300 \mathrm{mg}$ of cleaned bone samples from each specimen were demineralized in $0.5 \mathrm{M} \mathrm{HCl}$ solution at $5{ }^{\circ} \mathrm{C}$ until fully demineralization. Demineralized samples were rinsed three times with deionized water until $\mathrm{pH}$ became neutral. The samples were gelatinized at $70^{\circ} \mathrm{C}$ for $48 \mathrm{hr}$ using a heater block (FMH instruments, South Africa). This solution was filtered with a $9 \mathrm{ml}$ EZEE-filter (Elkay, United Kingdom) to remove small $(<8 \mu \mathrm{m})$ particles and ultrafiltered with $30 \mathrm{kDa}$ ultrafilters (Amicon, Germany) using a centrifuge (Thermo Fisher Scientific Megafuge 16, USA) at $2500 \mathrm{rpm}$ during variable times depending on the filtering speed of each sample. The final solution was then frozen and lyophilized for $48 \mathrm{hr}$. Finally, duplicate about $0.5 \mathrm{mg}$ of collagen per sample was weighed into tin capsules, and loaded into the mass spectrometer.

The carbon and nitrogen isotope ratio measurements were performed using a Finnigan Delta plus XP continuous-flow isotope ratio mass spectrometer (Thermo Fisher Scientific, USA) after being combusted in an elemental analyser Flash EA 1112 interfaced with it (Thermo Fisher Scientific, USA). Stable Carbon isotope ratios were expressed relative to the VPDB scale (Vienna Pee Dee Belemnite), and stable Nitrogen isotope ratios were measured relative to the AIR scale (atmospheric $\mathrm{N}_{2}$ ), using the delta notation $(\delta)$ in parts per thousand (\%). Repeated analysis of internal and international standards determined an analytical precision of $0.1 \%$ o $(1 \sigma)$ or less for $\delta^{13} \mathrm{C}$ and $\delta^{15} \mathrm{~N}$. All analyses were carried out in duplicate. 
TABLE 3 Cueva de Chaves S-UCT code, species, sampled bone, archaeological level, biological age group, $\delta^{13} \mathrm{C}$ and $\delta^{15} \mathrm{~N}$ average values, collagen control indicators (\%C, \%N, C:N elemental) and radiocarbon dates

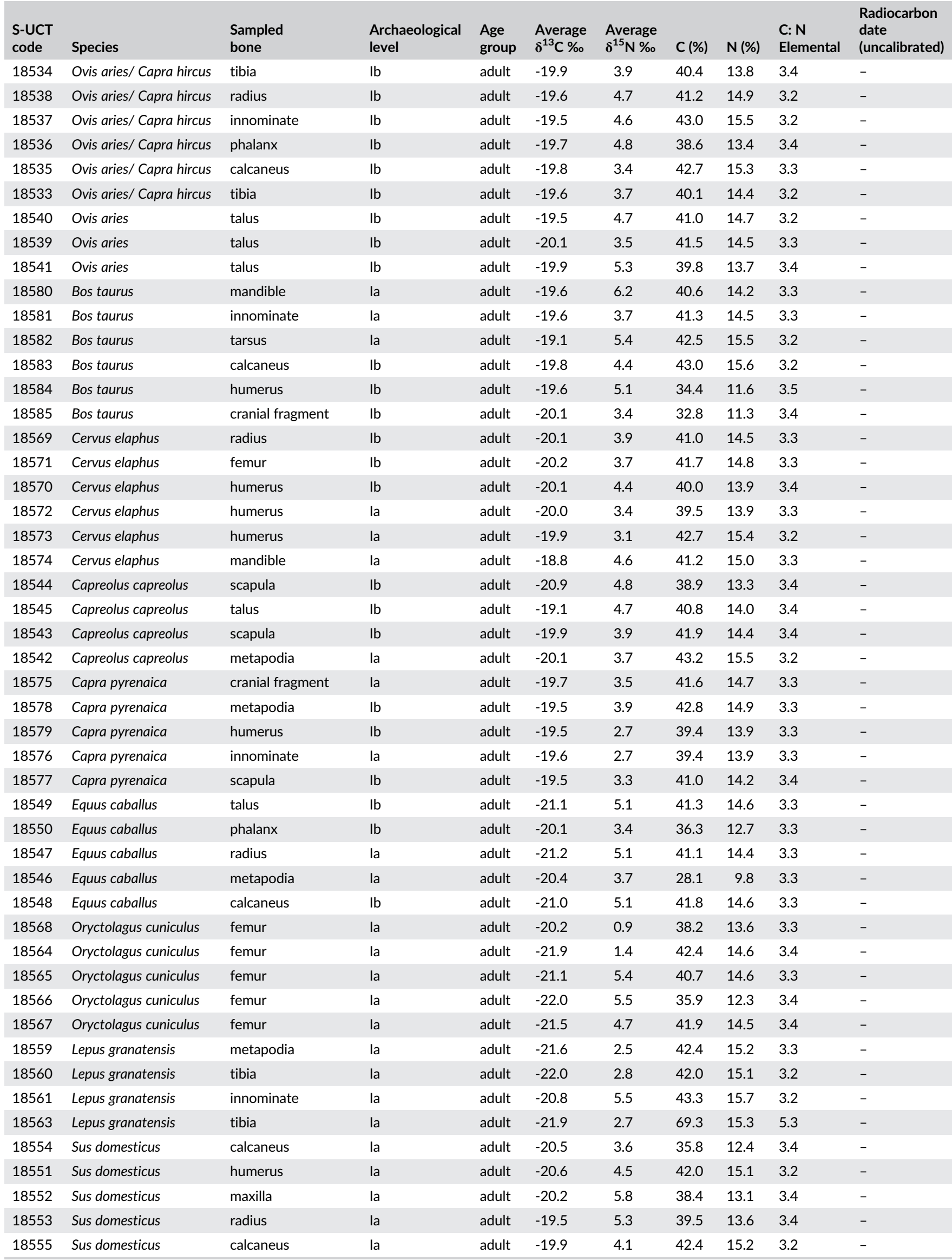


TABLE 3 (Continued)

\begin{tabular}{|c|c|c|c|c|c|c|c|c|c|c|}
\hline $\begin{array}{l}\text { S-UCT } \\
\text { code }\end{array}$ & Species & $\begin{array}{l}\text { Sampled } \\
\text { bone }\end{array}$ & $\begin{array}{l}\text { Archaeological } \\
\text { level }\end{array}$ & $\begin{array}{l}\text { Age } \\
\text { group }\end{array}$ & $\begin{array}{l}\text { Average } \\
\delta^{13} \mathrm{C} \%\end{array}$ & $\begin{array}{l}\text { Average } \\
\delta^{15} \mathrm{~N} \% \text { 。 }\end{array}$ & C (\%) & $\mathrm{N}(\%)$ & $\begin{array}{l}\mathrm{C}: \mathrm{N} \\
\text { Elemental }\end{array}$ & $\begin{array}{l}\text { Radiocarbon } \\
\text { date } \\
\text { (uncalibrated) }\end{array}$ \\
\hline 18586 & Meles meles & radius & $\mathrm{lb}$ & adult & -18.3 & 8.0 & 43.4 & 15.6 & 3.2 & - \\
\hline 18588 & Meles meles & vertebra & $\mathrm{lb}$ & adult & -18.1 & 7.5 & 42.1 & 15.2 & 3.2 & - \\
\hline 18594 & Meles meles & mandible & la & adult & -18.3 & 7.6 & 43.9 & 15.5 & 3.3 & - \\
\hline 18591 & Canis sp. & metatarsus & la & adult & -19.5 & 6.0 & 40.6 & 14.2 & 3.3 & - \\
\hline 18592 & Canis sp. & scapula & la & adult & -18.2 & 7.6 & 42.6 & 15.4 & 3.2 & - \\
\hline 18593 & Canis sp. & tibia & la & adult & -19.3 & 9.9 & 43.4 & 15.3 & 3.3 & - \\
\hline 18525 & Felis silvestris & ulna & $\mathrm{lb}$ & adult & -19.1 & 6.8 & 42.0 & 15.0 & 3.3 & - \\
\hline 18595 & Vulpes vulpes & cranial fragment & la & adult & -18.2 & 7.9 & 42.0 & 15.2 & 3.2 & - \\
\hline 18589 & Buteau buteau & radius & la & adult & -20.0 & 8.8 & 42.7 & 15.2 & 3.3 & \\
\hline 19600 & Homo sapiens & mandible & la & adult & -19.1 & 9.0 & 37.7 & 13.2 & 3.3 & $5645 \pm 31$ \\
\hline 21023 & Homo sapiens & mandible & la & infant & -19.1 & 8.8 & 40.2 & 13.8 & 3.4 & $6180 \pm 54$ \\
\hline 21024 & Homo sapiens (84C) & phalanx & la & adult & -18.5 & 10.6 & 44.0 & 15.6 & 3.3 & $6230 \pm 45$ \\
\hline 21025 & Homo sapiens & mandible & la & adult & -19.4 & 9.5 & 44.3 & 16.0 & 3.3 & $6227 \pm 28$ \\
\hline
\end{tabular}

\section{3 | RESULTS}

Bone samples from 4 humans and 64 animals were analyzed from the Early Neolithic levels of Cueva de Chaves. The $\delta^{13} \mathrm{C}$ and $\delta^{15} \mathrm{~N}$ results are presented in Table 3 and plotted in Figure 4. All the samples from Cueva de Chaves yielded enough collagen from the $>30 \mathrm{kDa}$ fraction for analysis in duplicate, and \%C (around $\geq 30$ ), \%N (around $\geq 10$ ) and $\mathrm{C}: \mathrm{N}$ ratio (2.9-3.6) values indicate a good collagen quality, according to Ambrose (1993), De Niro (1985), and Van Klinken (1999). The $\delta^{13} \mathrm{C}$ and $\delta^{15} \mathrm{~N}$ values were obtained from the $>30 \mathrm{kDa}$ fraction of the lyophilized collagen.
Herbivore $\delta^{13} \mathrm{C}$ values range between $-22.0 \%$ and $-18.8 \%$ with a mean value of $-20.2 \pm 0.8[1 \sigma] \%$. The taxa with the smallest $\delta^{13} \mathrm{C}$ values are rabbits and hares, which usually present ${ }^{13} \mathrm{C}$ depleted values in the region (Salazar-García et al., 2014; VillalbaMouco et al., 2018), and show a high deviation. Herbivore $\delta^{15} \mathrm{~N}$ values range between $0.9 \%$ and $6.2 \%$, with a mean value of $4.0 \pm 1.1[1 \sigma] \%$, defining the trophic baseline of the ecosystem foodweb. In this case, rabbit and hares also present the lowest values and the highest deviation of $\delta^{15} \mathrm{~N}$ values (see Table 1, Figure 3). These herbivore $\delta^{13} \mathrm{C}$ and $\delta^{15} \mathrm{~N}$ values are consistent with typical values for a terrestrial $C_{3}$ European ecosystem (De Niro and

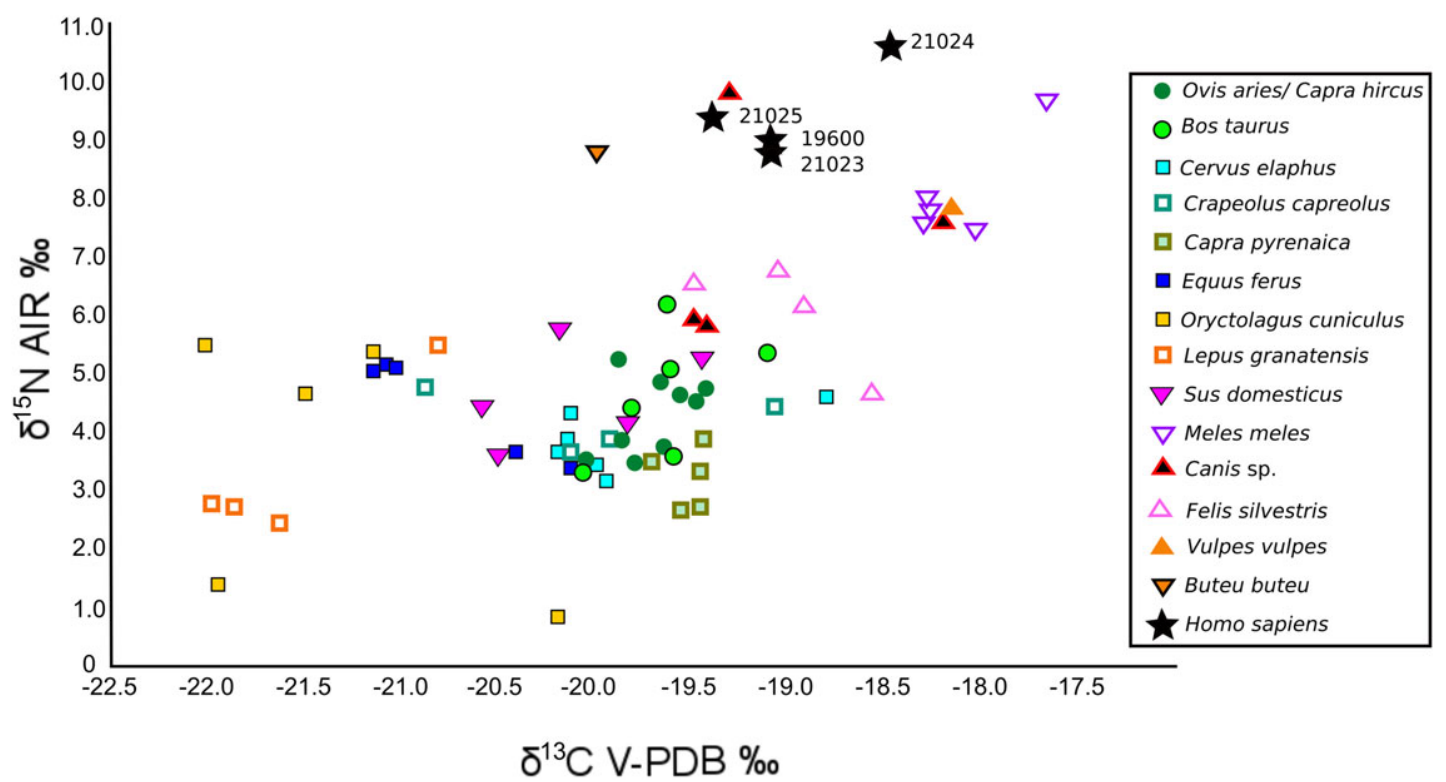

FIGURE 4 Scatter plot of human and fauna bone collagen $\delta^{13} \mathrm{C}$ and $\delta^{15} \mathrm{~N}$ values from Cueva de Chaves. The $\mathrm{X}$ and $\mathrm{Y}$ axes are plotted at different scales in order to make all the samples more visible [Color figure can be viewed at wileyonlinelibrary.com] 
Epstein, 1978; Schwarcz and Schoeninger, 1991). If we divide the sample between domestic (Ovis/Capra and Bos taurus; $\delta^{13} \mathrm{C}$ mean: $-19.7 \pm 0.2[1 \sigma] \% ; \delta^{15} \mathrm{~N}$ mean: $\left.4.4 \pm 0.8[1 \sigma] \% \circ\right)$ and nonlagomorph wild herbivores (Cervus elaphus, Capreolus capreolus, Capra pyrenaica and Equus caballus; $\delta^{13} \mathrm{C}$ mean: $-20.0 \pm 0.6[1 \sigma] \%$; $\delta^{15} \mathrm{~N}$ mean: $3.9 \pm 0.8[1 \sigma] \%$ ), they show no differences in $\delta^{13} \mathrm{C}$ $(p=0.074)$ nor $\delta^{15} \mathrm{~N}(p=0.086)$ values.

Domestic pig livestock (Sus domesticus) were classically considered as potential omnivores. Their $\delta^{13} \mathrm{C}$ values range between $-20.6 \%$ and $-19.5 \%$, with a mean value of $-20.1 \pm 0.5[1 \sigma] \%$ ond place them in the same range as all other medium- and large-sized herbivores. Their $\delta^{15} \mathrm{~N}$ values range between $3.6 \%$ and $5.8 \%$, with a mean value of $4.7 \pm 0.9[1 \sigma] \%$, which does not show the increase expected for a change of trophic level (Bocherens and Drucker, 2003; Minagawa and Wada, 1986). A nonparametric Mann Whitney test indicates no significance differences between the means for herbivores (not including ${ }^{13} \mathrm{C}$ depleted lagomorphs) and pigs in $\delta^{13} \mathrm{C}\left(p\right.$ : 0.260) or in $\delta^{15} \mathrm{~N}(p: 0.236)$.

Carnivore $\delta^{13} \mathrm{C}$ values range between $-20.0 \%$ and $-17.7 \%$, with a mean value of $-18.8 \pm 0.7[1 \sigma] \%$, and their $\delta^{15} \mathrm{~N}$ values range between $4.7 \%$ ond $9.9 \%$, with a mean value of $7.4 \pm 1.4[1 \sigma] \%$. These values position them in a higher trophic level than both herbivores and potential omnivores. Overall, the non-parametric Mann Whitney test shows significant differences between pigs and carnivores in $\delta^{13} \mathrm{C}$ ( $p$ : 0.004) and $\delta^{15} \mathrm{~N}(p: 0.003)$ values. However, the non-parametric Kruskal Wallis test reveals significant differences in $\delta^{13} \mathrm{C}$ values between Canis sp., Felis silvestris, and Meles meles ( $p$ : 0.043). Dunn's Post Hoc test also shows further significant differences between Meles meles and Felis silvestris ( $p$ : 0.033 ) and between Meles meles and Canis sp ( $p$ : 0.033). These significant differences can define the specific diet of each species. Only Felis silvestris and Canis sp. appear to have an isotopically similar diet (Dunn's Post Hoc test $p:$ 1.000). The non-parametric Kruskal Wallis test reveals no significant differences in $\delta^{15} \mathrm{~N}$ values between Canis sp., Felis silvestris, and Meles meles (p: 0.089). Vulpes vulpes and Buteu buteu are not included in the statistical analysis because of their low sample number.

The four human $\delta^{13} \mathrm{C}$ values (including the subadult individual) range between $-19.4 \%$ and $-18.5 \%$, with a mean value of $-19.0 \pm 0.4[1 \sigma]$ $\%$, and the $\delta^{15} \mathrm{~N}$ values are between $8.8 \%$ ond $10.6 \%$, with a mean value of $9.5 \pm 0.8[1 \sigma] \%$. These average values portray a terrestrial diet based mainly on $\mathrm{C}_{3}$ terrestrial resources, and defines the highest values of the local trophic ecosystem foodweb. Of interest is that the only individual recovered from an actual Cardial burial shows higher $\delta^{13} \mathrm{C}$ (by $0.7 \%$ ) and $\delta^{15} \mathrm{~N}$ (by $1.5 \%$ ) values than the average from the other three individuals. In any case, because of the low number of samples, these results need to be interpreted with caution (Figure 4).

\section{4 | DISCUSSION}

\subsection{Wild and domestic herbivores}

No significant differences were found between wild and domestic herbivores. These similar values could point towards a possible common plant resource consumption for both wild and domestic herbivores. Different environmental factors may have an effect on stable isotope values (Drücker et al., 2003; Goude and Fontugne, 2016). The $\delta^{13} \mathrm{C}$ values help to distinguish between open or close-forested environments, with the plants that grow in closed environments showing lower $\delta^{13} \mathrm{C}$ values (O'Leary, 1981; Tieszen, 1991); the $\delta^{15} \mathrm{~N}$ values increase due to arid conditions or vary depending on soil type (Ambrose, 1993; Handley et al., 1999). Therefore, another possible explanation for these similar values between wild and domestic species could be linked to a shared environment and/or the use of the same parts of the landscape for grazing. These data could suggest foddering domestic animals with wild plants. The use of wild plants such as Juniperus for foddering was previously suggested by an anthracological study in the most recent Early Neolithic level (Alcolea et al., 2017). The use of Juniperus as fodder has been documented in the Central Pyrenees (Villar and Fernández, 2000) and in ovicaprine coprolites from the prehistoric La Fangade archaeological site in France (Bouby, 2014; Chabal et al., 2009).

In either scenario, the use of wild plant species as fodder for domestic animals reflect that the population relied more on animal husbandry than agricultural practices. This hypothesis is in agreement with palynological studies that suggest a low impact of crop management at the site except during the last stages of the Early Neolithic (López García and López Sáez, 2000). Some authors suggest that this could be the result of not having potential agricultural fields close to Cueva de Chaves (Mazzucco et al., 2015). In this sense, the absence of grains makes it isotopically difficult to test if manuring practices played an important role in the early stages of Iberian Neolithic agriculture. However, the fact that both wild and domestic animals have a similar $\delta^{15} \mathrm{~N}$ values suggests that no manure signal is present (Bogaard, Heaton, Poulton, \& Merbach, 2007; Bogaard et al., 2013).

The Cueva de Chaves domestic herbivore data also present little dispersion. Specifically, domestic ovicaprids show the smallest dispersion in both $\delta^{13} \mathrm{C}$ and $\delta^{15} \mathrm{~N}$ values and suggest a common environment and feeding that could be associated with stabling practices to protect the livestock from the wild carnivores as described for other Iberian Early Neolithic sites (Oms et al., 2014b; Saña et al., 2015). This common feeding/environment would imply the absence of sheep flocks or transhumance activities amongst the Early Neolithic community living in the cave (Martín et al., 2015). However, since bulk bone collagen reflects an average of the last years of life, it is difficult to find differences in isotopic values resulting from the seasonal movements between environments; sequential $\delta^{13} \mathrm{C}$ and $\delta^{18} \mathrm{O}$ isotopic analysis of teeth would be necessary to prove the absence of these types of husbandry practices (Tornero et al., 2016, 2018). Even so, nontranshumance activities would be in agreement with the characteristics of a big settlement such as Cueva de Chaves, and would confirm that it was not a site for short residence periods as is typical for mountain sites linked to sheep-herding activities (Rojo-Guerra et al., 2013).

Isotopic tests between wild and domestic herbivores have been carried out in order to test differences in husbandry management practices in other contemporary Iberian sites such as La Draga or Cova de Frare (Navarrete et al., 2017). At the first site, the domestic fauna showed higher $\delta^{13} \mathrm{C}$ and $\delta^{15} \mathrm{~N}$ values (Navarrete et al., 2017). These slight isotopic differences could suggest different feeding strategies, such us using agricultural crops as one of the potential fodders for domestic species. The reason for these higher $\delta^{13} \mathrm{C}$ and $\delta^{15} \mathrm{~N}$ values could be the use of natural fertilizers. Although the presence of 
crops in La Draga is clear (Antolín, 2016; Antolín and Buxó, 2011;), the increase in $\delta^{15} \mathrm{~N}$ values is quite low to propose an intensive manuring effect (Bogaard et al., 2013). However, the other Early Neolithic site, Cova de Frare, presents no isotopic differences between wild and domestic herbivores (Navarrete et al., 2017), likewise as observed at Cueva de Chaves.

\section{2 | Omnivores: Pig livestock}

Suids are omnivores with a flexible ecological niche because of their opportunistic feeding (Macdonald and Barrett, 1993; Schley and Roper, 2003). Humans have taken advantage of this to feed domestic pigs (Sus domesticus) with whatever suited them. As a result, the diet of pigs has proved to reflect many aspects of human community structure in both prehistoric (Madgwick, Mulville, \& Stevens, 2012) and historic periods (Halley and Roslvold, 2014). In this sense, two main management models for pig husbandry have been proposed. The first one is based on a free-range management where pigs feed on their own and most of the diet comes from plants (Madgwick et al., 2012), resulting in an herbivorous isotopic signal. The other one is the household management one, where pigs feed on leftovers and human debris and therefore commonly show a mixed isotopic signature resulting from combining the different types of foods consumed by humans in each case (Balasse et al 2016; Madgwick et al., 2012; Müldner and Richards, 2005; Privat, O'connell, \& Richards, 2002; Richards, Fuller, \& Molleson, 2006). Some authors consider that both suid husbandry management models can occur simultaneously in what is called a "household model" with mixed diets only depending on the size of livestock (Navarrete et al., 2017). Other authors argue that pig management practices change according to the chrono-cultural period, showing more household feeding of pigs in historic rather than prehistoric times (Madgwick et al., 2012).

Domestic pigs from Cueva de Chaves show a significant difference in their $\delta^{13} \mathrm{C}\left(p\right.$ : 0.007) and $\delta^{15} \mathrm{~N}$ ( $p$ : 0.007) values with carnivores, but no significant difference with herbivores from the same ecosystem $\left(\delta^{13} \mathrm{C}=p\right.$ : $0.237 ; \delta^{15} \mathrm{~N}=p$ : 0.203). Having the same $\delta^{15} \mathrm{~N}$ range as herbivores shows they are in a same trophic level, ruling out a significant input of animal protein in their diet (Bocherens and Drucker 2003). The $\delta{ }^{15} \mathrm{~N}$ values are also the same for ruminant and non-ruminant herbivores, suggesting that isotopic digestive fractionation could cause an incorrect herbivore profile in pigs (Halley and Rosvold, 2014; Hedges, 2003). This herbivore trophic attribution would be compatible with a free-range pig husbandry management similar to what is proposed for the Early Neolithic Iberian sites of Cova del Frare and Serra de Mas Bonet (Navarrete et al., 2017). However, and contrary to what is observed at these sites, Cueva de Chaves has a large-sized pig livestock, more similar to the one from La Draga where an herbivore pig diet has also been suggested (Navarrete et al., 2017). Furthermore, Cueva de Chaves is one of the biggest pig husbandry communities in the Iberian Early Neolithic according to the number of pig remains recovered $(n=1217)$ (Castaños, 2004), followed by La Draga ( $n=1048$ ) (Saña, 2011), and shows mostly an infant and juvenile specimen slaughtering pattern as at La Draga (Saña, 2011). This kind of husbandry management is more usual in a household model (Halstead and Isaakidou, 2011), where number of pigs is limited by pig size, which is bigger as a result of feeding them with animal fat and protein in order to slaughter them earlier (Balasse et al., 2016).

All these aforementioned traits lead us to propose, a controlled and limited dispersion range for suid husbandry, or their keeping in an enclosure where they would be fed only plant foods (Hadjikoumis, 2012; Halstead and Isaakidou, 2011). In this sense, anthracological evidence shows the importance of acorns in Cueva de Chaves during the older Early Neolithic level (Alcolea et al., 2017; Zapata, Baldellou, \& Utrilla, 2008) when the presence of a woodland environment is suggested (Alcolea et al., 2017). The consumption of acorns could have decreased over time (Hamilton et al., 2009), parallel to the woodland clearing at the recent Early Neolithic level (Alcolea et al., 2017).

It is also necessary to consider that, as ethnography shows (Halstead and Isaakidou, 2011), a fattening diet based on animal products could take place at the end of the pig's life and would therefore not be shown in the collagen bulk signature. However, it seems that the overall introduction of leftover feeding of pigs happened over time, linked to the complexity of the settlements (Madgwick et al., 2012). An even bigger dataset would be required to get more in-depth information on pig management in the Neolithic levels from Cueva de Chaves.

\subsection{Wild and domestic carnivores}

The canine data show the highest dispersion inside the carnivore group. This could be translated into a heterogeneous feeding pattern that could be linked to their wild or domestic status. Two of them (SUCT 18592 and S-UCT 18593) are closer to the human isotopic values and could be associated to domestic adscription, because in that case most of their diet depends on human provided or leftover foods (Reitsema, Kozłowski, \& Makowiecki, 2013). This would be in agreement with the dog surrogacy hypothesis, which considers dogs to be a good proxy to recover information on prehistoric human diet whenever human remains are not available (e.g., Guiry and Grimes, 2013). The other two canine values (S-UCT 18590 and S-UCT 18591) show lower values than expected for a full carnivore diet but could be in agreement with a high consumption of depleted ${ }^{13} \mathrm{C}$ and ${ }^{15} \mathrm{~N}$ rabbits and hares and their wild adscription. It is also important to highlight that wolves are a highly mobile species and they can reflect the isotopic values from different environments (Blanco, 2017).

In the case of wild cats (Felis silvestris) their $\delta^{13} \mathrm{C}$ and $\delta^{15} \mathrm{~N}$ values do not show clear evidence of household feeding, suggesting a combination of human leftover and small prey hunting in their diet. Regarding other wild carnivores, only the data for one Vulpes vulpes is positioned inside the range of Meles meles. While Vulpes vulpes mainly feed on rabbits (López-Martín, 2017), Meles meles eat mainly earthworms but have a huge range of food resources including rabbits (Virgós, 2005), which are abundant in the Early Neolithic levels of Cueva de Chaves (Castaños, 2004). Because the Meles meles $\delta^{13} \mathrm{C}$ and $\delta^{15} \mathrm{~N}$ values are very close to those of Vulpes vulpes, it could be argued that the specimens analyzed consumed abundant rabbit. The problem when looking at the Chaves baseline is that rabbits have lower $\delta^{13} \mathrm{C}$ and $\delta^{15} \mathrm{~N}$ values than what would fit the pattern if Vulpes vulpes and Meles meles were mainly consuming them, so it is possible that both 
(a)

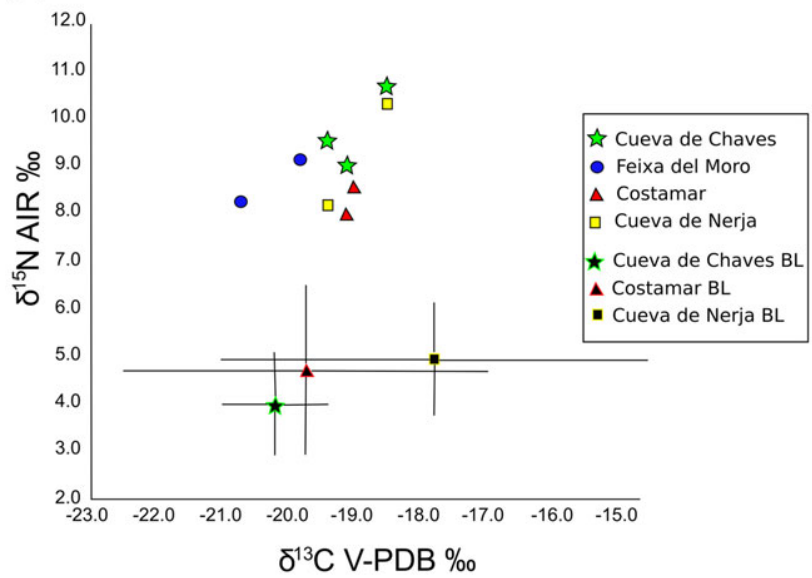

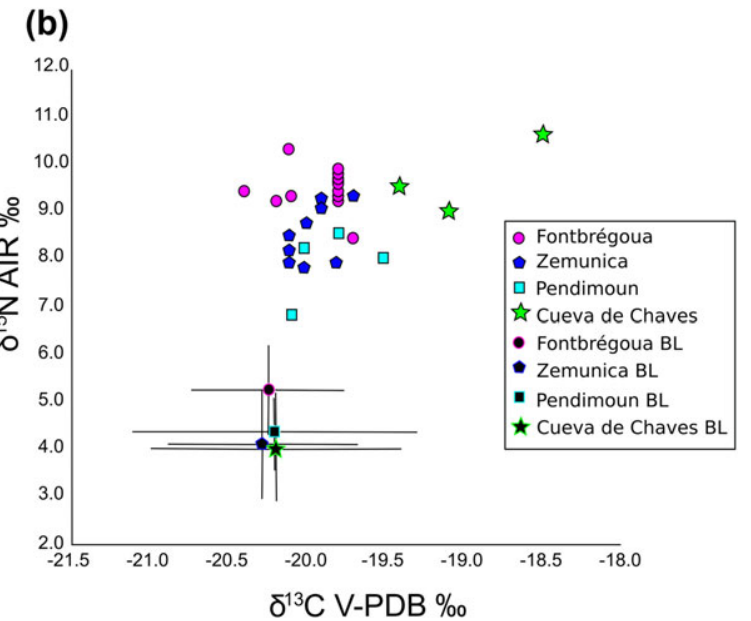

FIGURE 5 (a) Plot of bone collagen $\delta^{13} \mathrm{C}$ and $\delta^{15} \mathrm{~N}$ values of different Early Neolithic adult humans from Iberia [Costamar (Salazar-García, 2009); Cueva de Nerja (Salazar-García et al., 2017b); Feixa del Moro (Remolins et al., 2016) and Cueva de Chaves (this study)]; (b) Plot of bone collagen $\delta^{13} \mathrm{C}$ and $\delta^{15} \mathrm{~N}$ values of different Early Neolithic from the Western Mediterranean region [Fontbrégoua (France) (Le Bras-Goude et al., 2009), Pendimoun (Le Bras-Goude et al., 2006), 3: Zemunica (Croatia) (Guiry et al., 2017) and Cueva de Chaves (this study)]. The $X$ and $Y$ axes are plotted at different scales in order to make all the samples more visible. The $\delta^{13} \mathrm{C}$ and $\delta^{15} \mathrm{~N}$ baselines were calculated with contemporaneous herbivore data of each site when was available excluding domestic pigs. Subadult individuals were excluded; BL: Baseline [Color figure can be viewed at wileyonlinelibrary.com]

badgers and foxes also scavenged human refuse (López-Martín, 2017; Virgós, 2005). The addition of freshwater resources like amphibians or reptiles in the diet could be also compatible with the Meles meles isotopic values. The intermittent water flux of the ravines close to Cueva de Chaves (Ortega Becerril, 2010), however, makes the consumption of riverine fish less plausible.

\subsection{Human dietary reconstruction}

Humans from Cueva de Chaves present isotopic values that show a protein diet based mainly on $\mathrm{C}_{3}$ terrestrial resources. The $\delta^{15} \mathrm{~N}$ human values are $5.5 \%$ o higher than herbivore values (wild and domestic) and $4.8 \%$ higher than the suid values. Because there are no significant isotopic differences between wild and domestic herbivores, it is difficult to know which of these resources humans relied on more. Perhaps little of the protein intake came from lagomorphs and horses, which show lower $\delta^{13} \mathrm{C}$ values than what would be expected from the main protein source of the human diet. This would be compatible with the higher importance of domestic animal resources put forward by the zooarchaeological study (Castaños, 2004) (Table 2).

Regarding plant consumption, and keeping in mind the isotopic masking effect of animal protein on plant foods, the high $\delta^{15} \mathrm{~N}$ values could suggest that plant foods were not the central element of their protein diet, which would be based on animal resources (Bocherens and Drucker, 2003). Previous studies suggested a high consumption of plant resources at Cueva de Chaves based on the presence of a pit structure full of charred acorns dated back to the Early Neolithic (Zapata et al., 2008). However, isotopically it seems more probable that domestic animals (mainly suids) were fed acorns, which would have been consumed by humans only sporadically. Furthermore, there is no isotopic evidence whatsoever for the consumption of $\mathrm{C}_{4}$ resources.
Looking at the human sample in more detail, there is a quite homogeneous group of three individuals, including the subadult individual who does not show a breastfeeding or weaning signal (Fuller et al., 2006). Amongst this first group the $\delta^{15} \mathrm{~N}$ values are high and can be explained by abundant meat consumption (higher by $5.1 \%$ in $\delta^{15} \mathrm{~N}$ values and by $1 \%$ in $\delta^{13} \mathrm{C}$ values than herbivores). The single individual who does not cluster with the others is individual S-UCT 21024 , whose body was recovered from an special burial. This individual shows higher $\delta^{15} \mathrm{~N}$ and $\delta^{13} \mathrm{C}$ values (by $6.6 \%$ and $1.7 \%$ o higher than herbivores, respectively; $1.5 \%$ and $0.7 \%$ o higher than the other humans, respectively) (Figure 4). For this individual, a small input of another type of protein resource could be suggested, perhaps marine or estuarine protein consumption in low quantities but enough as to be recorded in the isotopic collagen composition. Cueva de Chaves is located close to the Solencio ravine, which presents a torrential water flux, something likely not compatible with the extensive presence of freshwater fish. Moreover, the higher $\delta^{15} \mathrm{~N}$ and $\delta^{13} \mathrm{C}$ values at the same time is more common for marine than freshwater resource consumption (Lillie, Budd, \& Potekhina, 2011). If this was the case and the individual had eaten marine or estuarine fish, as they are not available locally, this would be another point to support the existence of coastal-inland routes for this time period. This has been proposed previously by schematic rock art studies (Hernández Pérez, 2016; Utrilla and Baldellou, 2002) as well as by the huge set of Cardial pottery and marine shells used for Cardial decoration recovered at the site (Utrilla and Laborda, 2018).

When plotting together all the adult Early Neolithic humans from Iberia (3 sites, 9 adult humans including Cueva de Chaves), individual S-UCT 21024 from Cueva de Chaves shows the highest $\delta^{13} \mathrm{C}$ and $\delta^{15} \mathrm{~N}$ values only followed by one individual from Cueva de Nerja where a small $\mathrm{C}_{4}$ input has been suggested (Salazar-García et al. 2017b) (Figure 5a). In contrast to Cueva de Nerja, no faunal remains have shown typical values from $\mathrm{C}_{4}$ ecosystems at Cueva de Chaves, 
so the hypothesis of marine protein intake is more plausible for this individual, as well as due to the presence of a higher $\delta^{15} \mathrm{~N}$ increase at Cueva de Chaves than at Cueva de Nerja in comparison to their respective faunal baselines. This would imply that the Cueva de Chaves first farmers arrived to the lberian coast and penetrated fast into Iberia, and not through the Pyrenees as it was proposed in some works (Utrilla et al., 1998). Strontium isotope analysis in dental enamel could help to know more about the mobility of this Cardial individual with a special burial treatment during his life as long as the migration happened after the enamel mineralization and if the geology of the two areas (where the enamel mineralization took place and Cueva de Chaves) were different (Bentley 2013; Price, Burton, \& Bentley, 2002).

At a broader scale encompassing the Western Mediterranean (Salazar-García, Fontanals-Coll, Goude, \& Subirà, 2018), when plotting bone collagen $\delta^{13} \mathrm{C}$ and $\delta^{15} \mathrm{~N}$ values from different Early Neolithic adult humans, we see how Chaves fits into the expected Early Neolithic mainly terrestrial protein diet intake. Even so, humans from different sites present variability and they cluster depending on their location and suggesting that human diets are not similar between all communities, although the baselines for each site show an overlap. In this sense, we observe again that individuals from Cueva de Chaves exhibit a trend that corresponds to the consumption of a significant quantity of food items with high $\delta^{13} \mathrm{C}$ and $\delta^{15} \mathrm{~N}$ values and individual S-UCT 21024 from Cueva de Chaves is also positioned in the highest top-right part of the graph, perhaps due to some marine or estuarine protein intake (Figure $5 \mathrm{~b}$ ). In any case, comparing only humans from different ecosystems should be done with caution, as variations in the ecosystem baselines of each site might result in incomparable data.

\section{5 | CONCLUSIONS}

This study represents one of the few Early Neolithic isotope analysis studies carried out on the Iberian Peninsula where humans and a large set of fauna coming from the same chrono-cultural context have been analyzed together. While the number of domestic animal remains reflects the importance of animal husbandry at inland early farming communities, animal dietary strategies show a basic husbandry management. Domestic and wild species showed similar values, suggesting the use of common resources or areas for grazing. Even the domestic pig showed an herbivorous diet, ruling out a human leftover feeding. The human isotopic dietary study shows a high animal protein intake by all individuals. This high meat consumption would be related to the existence of a specialized animal husbandry management community in which agriculture was not intensively developed. The values from one individual might reflect a slight isotopic signature of marine or estuarine protein intake at some point of the individual's life. There was no isotopic evidence for the consumption of $\mathrm{C}_{4}$ resources either by humans or fauna.

\section{ACKNOWLEDGMENTS}

VVM, DCSG, PU, and CML designed this work, VVM carried out sampling and labwork, VVM and DCSG made the analysis and the data interpretation and VVM, DCSG, RL, PU, and JIL have contributed with the archaeological context. This study is part of VVM's Doctoral Thesis. VVM has a predoctoral scholarship funded by the Gobierno de Aragón and the Fondo Social Europeo (BOA20150701025), and carried out a research stay at the University of Cape Town funded by the Fundación Ibercaja-CAI (2016) and DCSG's UCT Research Developing Grant. DCSG acknowledges funding for this research from the BBVA Foundation (I Ayudas a Investigadores, Innovadores y Creadores Culturales). VVM, PU and RL are members of the Spanish project HAR2014-59042-P (Transiciones climáticas y adaptaciones sociales en la prehistoria de la Cuenca del Ebro), and VVM, PU, RL and JIL are members of the regional government of Aragón PPVE research group (H-07: Primeros Pobladores del Valle del Ebro). All authors thank the Museo de Huesca for allowing the use of their installations. They thank lan Newton for technical assistance, Maricruz Sopena for archaeological drawings, Marta Alcolea for her useful comments, Rafael Larma for the topography of the cave and James Fellows Yates for the proofreading in English.

\section{ORCID}

Vanessa Villalba-Mouco (D) http://orcid.org/0000-0002-9357-5238

Cristina Martínez-Labarga (D) http://orcid.org/0000-0003-0439-0379

\section{REFERENCES}

Alcolea, M., Utrilla, P., Piqué, R., Laborda, R., \& Mazo, C. (2017). Fuel and acorns: Early Neolithic plant use from Cueva de Chaves (NE Spain). Quaternary International, 457, 228-239.

Ambrose, S. H. (1993). Isotopic analysis of paleodiets: Methodological and interpretative considerations. In: M. K. Stanford (Ed.), Investigations of ancient human tissue: Chemical analyses in anthropology (pp. 59-130). Langhorne: Gordon and Breach Science Publishers.

Antolín, F. (2016). Local, intensive and diverse? Early farmers and plant economy in the North-East of the Iberian Peninsula (5500-2300 Cal BC). Advances in archaeobotany, 2, Groningen.

Antolín, F., \& Buxo, R. (2011). L'explotacio de les plantes al jaciment de la Draga: Contribució a la història de l'agricultura i de l'alimentació vegetal del neolític a Catalunya. In A. Bosch, J. Chinchilla, \& J. Tarrús (Eds.), El poblat lacustre del neolític antic de la draga: Excavacions de 2000-2005 (pp. 147-174). Girona: MAC-CASC.

Arias, P. (2007). Neighbours but diverse: Social change in northwest Iberia during the transition from the Mesolithic to the Neolithic (5500-4000 cal BC). In A. Whittle, \& V. Cummings (Eds.), Going over: The mesolithic-neolithic transition in North-West Europe, (pp. 53-71), Oxford: Oxford University Press.

Balasse, M., Evin, A., Tornero, C., Radu, V., Fiorillo, D., Popovici, D., ... Bălăşescu, A. (2016). Wild, domestic and feral? Investigating the status of suids in the Romanian Gumelniţa (5th mil. cal BC) with biogeochemistry and geometric morphometrics. Journal of Anthropological Archaeology, 42, 27-36.

Balasse, M., Tornero, C., Bréhard, S., Ughetto-Monfrin, J., Voinea, V., \& Bălășescu, A. (2014). Cattle and sheep herding at Cheia, Romania, at the turn of the fifth millennium cal BC: A view from stable isotope analysis. Proceedings of the British Academy, 198 115-142.

Baldellou, V. (2012). La Cueva de Chaves (Bastarás-Casbas, Huesca). SAGVNTVM Extra, 12, 141-144.

Bentley, R. A. (2013). Mobility and the diversity of early Neolithic lives: Isotopic evidence from skeletons. Journal of Anthropological Archaeology, 32, 303-312.

Bernabeu, J., García-Puchol, O., \& Orozco-Köhler, T. (2018). New insigts relating to the beginning of the Neolithic in the eastern Spain: Evaluating empirical data and modelled predictions. Quaternary International, 470, 439-450. 
Bernabeu, J., Molina, L., Esquembre, M. A., Ortega, J. R., Boronat, J. (2009). La cerámica impresa mediterránea en el origen del Neolítico de la Península Ibérica. De Méditerranéen Et D'ailleurs... Mèlanges Offerts à Jean Guilaine, (pp 83-95). Toulouse.

Binder, D., \& Sénépart, I. (2010). La séquence de I'Impresso-Cardial de l'abri Pendimoun et l'évolution des assemblages céramiques en Provence. In C. Manen, F. Convertini, D. Binder, \& I. Sénépart (Eds.), Premières sociétés paysannes de méditerranée occidentale. Structures des productions céramiques (pp. 149-167). Toulouse: Societé Préhistorique Fançanise, Mémoire, 51

Blanco, J. C. (2017). Lobo-Canis lupus. En: Enciclopedia virtual de los vertebrados españoles. In A. Salvador \& I. Barja (Eds.), Madrid: Museo Nacional de Ciencias Naturales. Available at: http://www. vertebradosibericos.org/

Bocherens, H., \& Drucker, D. (2003). Trophic level isotopic enrichment of carbon and nitrogen in bone collagen: Case studies from recent and ancient terrestrial ecosystems. International Journal of Osteoarchaeology, 13, 46-53.

Bogaard, A., Fraser, R., Heaton, T. H., Wallace, M., Vaiglova, P., Charles, M., ... Stephan, E. (2013). Crop manuring and intensive land management by Europe's first farmers. Proceedings of the National Academy of Sciences of the United States of America, 110, 12589-12594.

Bogaard, A., Heaton, T. H. E., Poulton, P., \& Merbach, I. (2007). The impact of manuring on nitrogen isotope ratios in cereals: Archaeological implications for reconstruction of diet and crop management practices. Journal of Archaeological Science, 34, 335-343.

Bosch, A., Chinchilla, J., \& Tarrús, J. (2011). El poblat lacustre del neolític antic de La Draga. Excavacions 2000-2005 (Vol. 9). Monografies del Centre d'Arqueologia Subaquatica de Catalunya.

Bouby, L. (2014). Agriculture dans le basin du rhône du bronze final à l'antiquité. Agrobiodiversité, economie, cultures. Toulousse: Archives d'Écologie Préhistorique.

Bronk Ramsey, C. (2009). Bayesian analysis of radiocarbon dates. Radiocarbon, 51, 337-360.

Brown, T. A., Nelson, D. E., Vogel, J. S., \& Southon, J. R. (1988). Improved collagen extraction by modified Longin method. Radiocarbon, 30, 171-177.

Castaños, P. M. (2004). Estudio arqueozoológico de los macromamíferos del Neolítico de la Cueva de Chaves (Huesca). Saldvie, 4, 125-172.

Chabal, L., Bouby, L., Figueiral, I., Catanzano, J., Leroy, F., Guibal, F., \& Greck, S. (2009). Vivre sur un littoral lagunaire au Bronze final: Milieu et activités humaines d'après les macrorestes végétaux du site palafittique de La Fangade, étang de Thau (Sète, Hérault). Des Hommes Et Des Plantes: Exploitation Du Milieu Et Gestion Des Ressources Végétales De La Préhistoire à Nos Jours, XXXe Rencontres Internat. d'Archéo. et D'Hist. d'Antibes, 22-24.

Davis, S. J., \& Simões, T. (2016). The velocity of ovis in prehistoric times: The sheep bones from early Neolithic Lameiras, Sintra, Portugal. In M. Diniz, C. Neves, \& A. Martins (Eds.), O neolítico em Portugal antes do horizonte 2020: Perspectivas em debate. Lisboa: Associação de arqueólogos portugueses (pp. 51-66). Monografias da AAP, Lisboa, Portugal.

De Niro, M. J. (1985). Postmortem preservation and alteration of in vivo bone collagen isotope ratios in relation to paleodietary reconstruction. Nature, 317, 806-809.

De Niro, M. J., \& Epstein, S. (1978). Influence of diet on the distribution of carbon isotopes in animals. Geochimica Et Cosmochimica Acta, 42, 495-506.

Domingo, R. (2009). Caracterización funcional de los microlitos geométricos: el caso del Valle del Ebro. El mesolítico geométrico en la Península Ibérica (pp. 375-389). Departamento de Ciencias de la Antigüedad, Universidad de Zaragoza, Zaragoza.

Domingo, R. (2014). Beyond Chaves: Functional analysis of neolithic blades from the Ebro Valley. In J. Marreiros, N. Bicho, \& J. F. Gibaja (Eds.), International conference on use-wear analysis 2012 (pp. 672-681) Faro.

Drucker, D., Bocherens, H., Bridault, A., \& Billiou, D. (2003). Carbon and nitrogen isotopic composition of red deer (Cervus elaphus) collagen as a tool for tracking palaeoenvironmental change during the Late- Glacial and Early Holocene in the northern Jura (France). Palaeogeogr Palaeoclimatol Palaeoecol, 195(3), 375-388.
Edwards, C. J., Bollongino, R., Scheu, A., Chamberlain, A., Tresset, A., Vigne, J. D., ... Burger, J. (2007). Mitochondrial DNA analysis shows a Near Eastern Neolithic origin for domestic cattle and no indication of domestication of European aurochs. Proceedings of the Royal Society, 274, 1377-1385.

Fernández, E., Pérez-Pérez, A., Gamba, C., Prats, E., Cuesta, P., Anfruns, J., ... Turbón, D. (2014). Ancient DNA analysis of 8000 B.C. Near Eastern farmers supports an early Neolithic pioneer maritime colonization of mainland Europe through Cyprus and Aegean Islands. PLOS Genetics, 10, e1004401-e1004416.

Fogel, M. L., Tuross, N., \& Owsley, D. W. (1989). Nitrogen isotope tracers of human lactation in modern and archaeological populations, Annual Report of the Director, Geophysical Laboratory 1988-89 (pp. 111-117). Carnegie Institute of Washington.

Fuller, B. T., Fuller, J. L., Harris, D. A., \& Hedges, R. E. M. (2006). Detection of breastfeeding and weaning in modern human infants with carbon and nitrogen stable isotope ratios. American Journal of Physical Anthropology, 129, 279-293.

Gamba, C., Fernández, E., Tirado, M., Deguilloux, M. F., Pemonge, M. H., Utrilla, P., ... Arroyo-Pardo, E. (2012). Ancient DNA from an Early Neolithic Iberian population supports a pioneer colonization by first farmers. Molecular Ecology, 21, 45-56.

García, B. P., Aura, T. E., Jordá Pardo, J. F., \& Salazar-García, D. C. (2014). La cerámica neolítica de la Cueva de Nerja (Málaga, España): salas del Vestíbulo y la Mina. Archivo de Prehistoria Levantina, 30, 81-131.

García-Borja, P., Salazar-García, D. C., Pérez, A., Pardo, S., \& Casanova, V. (2011). El Neolítico Antiguo Cardial y la Cova de la Sarsa (Bocairent, Valencia). Nuevas Perspectivas a Partir de su Registro Funerario. Munibe, 62, 175-195.

Goude, G., \& Fontugne, M. (2016). Carbon and nitrogen isotopic variability in bone collagen during the Neolithic period: Influence of environmental factors and diet. Journal of Archaeological Science, 70, 117-131.

Guilaine, J., \& Manen, C. (2007). From Mesolithic to early Neolithic in the western Mediterranean. In A. Whittle \& V. Cummings (Eds.), Going over: The mesolithic-neolithic transition in North-west Europe (Vol. 144, pp. 21-51). London: Proceedings of the British Academy.

Guiry, E. J., \& Grimes, V. (2013). Domestic dog (Canis familiaris) diets among coastal Late Archaic groups of northeastern North America: A case study for the canine surrogacy approach. Journal of Anthropological Archaeology, 32, 732-745.

Guiry, E. J., Karavanić, I., Klindžić, R. Š., Talamo, S., Radović, S., \& Richards, M. P. (2017). Stable isotope palaeodietary and radiocarbon evidence from the Early Neolithic Site of Zemunica, Dalmatia, Croatia. European Journal of Archaeology, 20, 235-256.

Hadjikoumis, A. (2012). Traditional pig herding practices in southwest lberia: Questions of scale and zooarchaeological implications. Journal of Anthropological Archaeology, 31, 353-364.

Halley, D. J., \& Rosvold, J. (2014). Stable isotope analysis and variation in medieval domestic pig husbandry practices in northwest Europe: Absence of evidence for a purely herbivorous diet. Journal of Archaeological Science, 49, 1-5.

Handley, L. L., Austin, A. T., Stewart, G. R., Robinson, D., Scrimgeour, C. M., Raven, J. A., ... Schmidt, S. (1999). The $15 \mathrm{~N}$ natural abundances $(\delta 15 \mathrm{~N})$ of ecosystem samples reflects measures of water availability. Aust J Plant Physiol, 26, 185-199.

Hamilton, J., Hedges, R. E., \& Robinson, M. (2009). Rooting for pigfruit: pig feeding in Neolithic and Iron Age Britain compared. Antiquity, 83(322), 998-1011.

Hedges, R. E., \& Reynard, L. M. (2007). Nitrogen isotopes and the trophic level of humans in archaeology. Journal of Archaeological Science, 34, 1240-1251.

Halstead, P., \& Isaakidou, V. (2011). A Pig Fed by Hand is Worth Two in the Bush: Ethnoarchaeology of Pig Husbandry in Greece and its Archaeological Implications. In U. Albarella \& A. Trentacoste (Eds.), Ethnozooarchaeology: The Present and Past of Human-Animal Relationships (pp. 160-174). Oxford: Oxbow.

Herrscher, E., Goude, G., \& Metz, L. (2017). Longitudinal study of stable isotope compositions of maternal milk and implications for the palaeo-diet of infants. Bulletins et Mémoires de la Société d'Anthropologie de Paris, 29 (3-4), 131-139. 
Hedges, R. E. (2003). On bone collagen-Apatite-carbonate isotopic relationships. International Journal of Osteoarchaeology, 13, 66-79.

Hedges, R. E., Clement, J. G., Thomas, C. D. L., \& O'connell, T. C. (2007) Collagen turnover in the adult femoral mid-shaft: Modeled from anthropogenic radiocarbon tracer measurements. American Journal of Physical Anthropology, 133, 808-816.

Hernández Pérez, M. S. (2016). Arte Macroesquemático vs. Arte Esquemático. Reflexiones en torno a una relación intuida. In J. J. Cabanilles, (Ed.), Del neolític a l'edat del bronze en el mediterrani occidental. Estudis en homenatge a bernat martí oliver (pp. 481-490), Servei d'Investigació Prehistòrica, Museu de Prehistória de Valéncia, Valéncia.

Hill, P. A. (1998). Bone remodelling. British Journal of Orthodontics, 25, 101-107.

Isern, N., Zilhão, J., Fort, J., \& Ammerman, A. J. (2017). Modeling the role of voyaging in the coastal spread of the Early Neolithic in the West Mediterranean. Proceedings of the National Academy of Sciences of the United States of America, 114, 897-902.

Le Bras-Goude, G., Binder, D., Formicola, V., Duday, H., Couture-Veschambre, C., Hublin, J. J., \& Richards, M. (2006). Stratégies de subsistance et analyse culturelle de populations néolithiques de Ligurie: Approche par l'étude isotopique $\left(\delta^{13} \mathrm{C}\right.$ et $\left.\delta^{15} \mathrm{~N}\right)$ des restes osseux. Bulletins Et Mémoires De La Société D'Anthropologie De Paris, $18,43-53$

Le Bras-Goude, G., Binder, D., Zemour, A., \& Richards, M. P. (2009). New radiocarbon dates and isotope analysis of Neolithic human and animal bone from the Fontbrégoua Cave (Salernes, Var, France). Journal of Anthropological Sciences, 88, 167-178.

Lee-Thorp, J. A. (2008). On isotopes and old bones. Archaeometry, 50, 925-950.

Lemmen, C., Gronenborn, D., \& Wirtz, K. W. (2011). A simulation of the Neolithic transition in Western Eurasia. Journal of Archaeological Science, 38, 3459-3470.

Lillie, M., Budd, C., \& Potekhina, I. (2011). Stable isotope analysis of prehistoric populations from the cemeteries of the Middle and Lower Dnieper Basin, Ukraine. Journal of Archaeological Science, 38, 57-68.

Lillie, M. C., \& Richards, M. (2000). Stable isotope analysis and dental evidence of diet at the Mesolithic-Neolithic transition in Ukraine. Journal of Archaeological Science, 27, 965-972.

Longin, R. (1971). New method of collagen extraction for radiocarbon dating. Nature, 230, 241-242.

López García, P. (1992). Análisis polínicos de cuatro yacimientos arqueológicos situados en el Bajo Aragón. In P. Utrilla (Ed.), Aragón/Litoral mediterráneo. Intercambios culturales durante la prehistoria (pp. 235-242). Zaragoza: Institución Fernando el Católico.

López García, P., \& López Sáez, J. A. (2000). Le paysage et la phase épipaléolithique-mésolithique dans les Pre-Pyrénées aragonaises et le bassin moyen de l'Ebre à partir de l'analyse palynologique, en Les derniers chasseurs cueilleurs d'Europe occidentale (13.000-5.5000 av J.C.). Annales Littéraires, 699, 59-69.

López-Martín, J. M. (2017). Zorro-Vulpes vulpes. In: A. Salvador \& I. Barja (Eds.), Enciclopedia virtual de los vertebrados españoles. Madrid: Museo Nacional de Ciencias Naturales. http://www.vertebradosibericos.org/

Lubell, D., Jackes, M., Schwarcz, H., Knyf, M., \& Meiklejohn, C. (1994). The Mesolithic-Neolithic transition in Portugal: Isotopic and dental evidence of diet. Journal of Archaeological Science, 21, 201-216.

Madgwick, R., Mulville, J., \& Stevens, R. E. (2012). Diversity in foddering strategy and herd management in late Bronze Age Britain: An isotopic investigation of pigs and other fauna from two midden sites. Environmental Archaeology, 17, 126-140.

Manning, K., Timpson, A., Colledge, S., Crema, E., Edinborough, K., Kerig, T., \& Shennan, S. (2014). The chronology of culture: A comparative assessment of European Neolithic dating approaches. Antiquity, 88, 1065-1080.

Martins, H., Oms, F. X., Pereira, L., Pike, A., Rowsell, K., \& Zilhão, J. (2015). Radiocarbon dating the beginning of the Neolithic in Iberia: New results, new problems. Journal of Mediterranean Archaeology, 28, 105-131.

Mazzucco, N., Clemente-Conte, I., Gassiot, E., \& Gibaja, J. F. (2015). Insights into the economic organization of the first agro-pastoral communities of the NE of the Iberian Peninsula: A traceological analysis of the Cueva de Chaves flaked stone assemblage. Journal of Archaeological Science: Reports, 2, 353-366.

Macdonald, D., \& Barrett, P. (1993). Collins field guide: Mammals of Britain and Europe (pp. 197). London: Harper Collins Publishers.

Minagawa, M., \& Wada, E. (1986). Nitrogen isotope ratios of red tide organisms in the East China Sea: A characterization of biological nitrogen fixation. Marime Chemistry, 19, 245-259.

Müldner, G., \& Richards, M. P. (2005). Fast or feast: Reconstructing diet in later medieval England by stable isotope analysis. Journal of Archaeological Science, 32, 39-48.

Navarrete, V., Colonese, A. C., Tornero, C., Antolín, F., Von Tersch, M., Subirà, M. E., ... Saña, M. (2017). Feeding management strategies among the early Neolithic pigs in the NE of the Iberian Peninsula. International Journal of Osteoarchaeology, 27(5), 839-852.

Navarrete, V., \& Saña, M. (2017). Size changes in wild and domestic pig populations between 10,000-800 cal BC in the Iberian Peninsula: Evaluation of natural versus social impacts in animal populations during the first domestication stages. The Holocene. http://dx.doi.org/10.1177\% 2F0959683617693902

O'Leary, M. H. (1981). Carbon isotope fractionation in plants. Phytochemistry, 20(4), 553-567.

Olalde, I., Schroeder, H., Sandoval-Velasco, M., Vinner, L., Lobón, I., Ramirez, O., ... Lalueza-Fox, C. (2015). A common genetic origin for early farmers from Mediterranean Cardial and Central European LBK cultures. Molecular Biology and Evolution, 32, 3132-3142.

Oms, F. X., Cebrià, A., Morales, J. I., \& Pedro, M. (2015). Una inhumació cardial a la cova Foradada (Calafell, Baix Penedès)? In X. Esteve, C. Miró, M. Molist, \& G. Sabaté (Eds.), Jornades d'Arqueologia del penedès (pp. 59-64). Vilafranca del Penedès: Institut d'Estudis Penedesencs.

Oms, F. X., Daura, J., Sanz, M., Mendiela, S., Pedro, M., \& Martínez, P. (2017). First evidence of collective human inhumation from the cardial neolithic (Cova Bonica, Barcelona, NE Iberian Peninsula). Journal of Field Archaeology, 42, 43-53.

Oms, F. X., Esteve, X., Mestres, J., Martín, P., \& Martins, H. (2014a). La neolitización del nordeste de la Península Ibérica: Datos radiocarbónicos y culturales de los asentamientos al aire libre del Penedés. Trabajos De Prehistoria, 71, 42-55.

Oms, F. X., López-García, J. M., Mangado, X., Martín, P., Mendiela, S., Morales, J. I., ... Yubero, M. (2014b). Hàbitat en cova i espai pels ramats ca. 6200-6000 BP: Dades preliminars de la Cova Colomera (Prepirineu de Lleida) durant el neolític antic. Sagvntvm. Papeles Del Laboratorio De Arqueología De Valencia, 45, 25-38.

Ortega Becerril, J. A. (2010). El estudio de la morfología de los ríos en roca. Implicaciones hidrológicas y evolutivas en dos barrancos españoles. Boletín Geológico y Minero, 118, 803-811.

Pou, R., Martí, M., Jordana, X., Malgosa, A., \& Gibaja, F. J. (2010). L'enterrament del Neolític antic de la Plaça Vila de Madrid (Barcelona): Una estructura funerària del Vlè millennia $\mathrm{aC}$. Quarhis, 6, 94-107.

Price, T. D., Burton, J. H., \& Bentley, R. A. (2002). The characterization of biologically available strontium isotope ratios for the study of prehistoric migration. Archaeometry, 44, 117-135.

Privat, K. L., O'connell, T. C., \& Richards, M. P. (2002). Stable isotope analysis of human and faunal remains from the Anglo-Saxon cemetery at Berinsfield, Oxfordshire: Dietary and social implications. Journal of Archaeological Science, 29, 779-790.

Reimer, P. J., Bard, E., Bayliss, A., Beck, J. W., Blackwell, P. G., Bronk Ramsey, C., ... Van der Plicht, J. (2013). IntCal13 and Marine13 radiocarbon age calibration curves 0-50,000 Years cal BP. Radiocarbon, 55, 1869-1887.

Reitsema, L. J., Kozłowski, T., \& Makowiecki, D. (2013). Humanenvironment interactions in medieval Poland: A perspective from the analysis of faunal stable isotope ratios. Journal of Archaeological Science, 40, 3636-3646.

Remolins, G., Gibaja, J. F., Allièse, F., Fontanals, M., Martin, P., Masclans, A., ... Llovera, X. (2016). The Neolithic necropolis of La Feixa del Moro (Juberri, Andorra): New data on the first farming communities in the Pyrenees. Comptes Rendus Palevol, 15, 537-554.

Richards, M. P., Fuller, B. T., \& Molleson, T. I. (2006). Stable isotope palaeodietary study of humans and fauna from the multi-period (Iron Age, 
Viking and Late Medieval) site of Newark Bay, Orkney. Journal of Archaeological Science, 33, 122-131.

Rojo-Guerra, M. A., Kunst, M., Garrido-Pena, R., \& García-Martínez de Lagrán, I. (2006). La neolitización de la meseta norte a la luz del c-14: Análisis de 47 dataciones absolutas inéditas de dos yacimientos domésticos del valle de Ambrona, Soria, España. Archivo De Prehistoria Levantina, 26, 39-100.

Rojo-Guerra, M., Peña-Chocarro, L., Royo, J. I., Tejedor, C., García-Martínez de Lagrán, I., Arcusa, H., ... Alt, K. W. (2013). Pastores trashumantes del Neolítico antiguo en un entorno de alta montaña: secuencia crono-cultural de la Cova de Els Trocs (San Feliú de Veri, Huesca). BSAA Arqueología, 79, 9-55.

Salazar-García, D. C. (2009). Estudio de la dieta en la población neolítica de Costamar. Resultados preliminares de análisis de isótopos estables de Carbono y Nitrógeno. In E. Flors (Ed.), Torre la Sal (ribera de cabanes, castellón). la evolución del paisaje antrópico desde la prehistoria hasta el medievo (pp. 411-418). Monografies de Prehistòria i Arqueologia Castellonenques 8. archaeology, Springer.

Salazar-García, D. C., Aura, J. E., Olária, C. R., Talamo, S., Morales, J. V., \& Richards, M. P. (2014). Isotope evidence for the use of marine resources in the Eastern Iberian Mesolithic. Journal of Archaeological Science, 42, 231-240.

Salazar-García, D. C., \& García-Puchol, O. (2017a). Current thoughts on the Neolithisation process of the Western Mediterranean. In O. García-Puchol \& D. C. Salazar-García (Eds.), Times of neolithic transition along the Western mediterranean (pp. 1-11), Springer, Cham.

Salazar-García, D. C., Fontanals-Coll, M., Goude, G., \& Subirà, E. (2018). To "seafood" or not to 'seafood'?" An isotopic perspective on dietary preferences at the Mesolithic-Neolithic transition in the Western Mediterranean. Quaternary International, 470, 497-510.

Salazar-García, D. C., Pérez-Ripoll, M., García-Borja, P., \& Jordá Pardo, J. F. (2017b). A terrestrial diet close to the coast: A case study from the Neolithic levels of Nerja Cave (Málaga, Spain). In O. García-Puchol \& C. Salazar-García (Eds.), Times of neolithic transition along the Western Mediterranean (pp. 281-307). Springer: Fundamental Issues in Archaeology.

Sánchez, P. (2013). La organización microespacial del Neolítico de la cueva de Chaves. Bolskan, 24, 11-25.

Saña, M. (2011). La gestió dels recursos animals. In A. Bosch, J. Chinchilla, \& J. Tarrús (Eds.), El poblat lacustre del neolític antic de la draga. Excavacions 2000-2005 (pp. 177-212). Girona: Museu d'Arqueologia de Catalunya (Monografies del CASC, 9).

Saña, M., Antolín, F., Zapata, M., Castells, L., Craig, O. E., Benaiges, M. E., \& Spiteru, C. (2015). Prácticas agropecuarias durante el Neolítico antiguo y medio en la cueva de Can Sadurní (Begues, Barcelona). In V. Gonçalves, M. Dinz, \& A. C. Sousa (Eds.), V congresso do neolítico peninsular (pp. 57-66). Lisboa: Centro do Arqueologia da Universidade de Lisboa.

Schley, L., \& Roper, T. J. (2003). Diet of wild boar Sus scrofa in Western Europe, with particular reference to consumption of agricultural crops. Mammal Review, 33, 43-56.

Schoeninger, M. J., \& DeNiro, M. J. (1984). Nitrogen and carbon isotopic composition of bone collagen from marine and terrestrial animals. Geochimica Et Cosmochimica Acta, 48, 625-639.

Schulting, R. J. (1998). Slighting the sea: Stable isotope evidence for the transition to farming in northwestern Europe. Documenta Praehistorica, 25,18 .

Schwarcz, H. P., \& Schoeninger, M. J. (1991). Stable isotope analysis in human nutritional ecology. American Journal of Physical Anthropology, 34, 283-321.

Tieszen, L. L. (1991). Natural variations in the carbon isotope values of plants: implications for archeology, ecology and paleoecology. Journal of Archaeological Science, 18, 227-248.

Tornero, C., Aguilera, M., Ferrio, J. P., Arcusa, H., Moreno-García, M., Garcia-Reig, S., \& Rojo-Guerra, M. (2018). Vertical sheep mobility along the altitudinal gradient through stable isotope analyses in tooth molar bioapatite, meteoric water and pastures: A reference from the Ebro valley to the Central Pyrenees. Quaternary International, 484, 94-106.

Tornero, C., Balasse, M., Bălăşescu, A., Chataigner, C., Gasparyan, B., \& Montoya, C. (2016). The altitudinal mobility of wild sheep at the Epigravettian site of Kalavan 1 (Lesser Caucasus, Armenia): Evidence from a sequential isotopic analysis in tooth enamel. Journal of Human Evolution, 97, 27-36.

Ubelaker, D. H. (1989). Human skeletal remains: excavation, analysis, interpretation. In Manual on Archaeology 2 Taraxacum (first ed.) Washington.

Utrilla, P., Cava, A., Alday, A., Baldellou, V., Barandiaran, I., Mazo, C., \& Montes, L. (1998). Le passage du mésolithique au néolithique ancien dans le Bassin de l'Ebre (Espagne) d'après les datations C14. Préhistoire européenne, 12, 171-194.

Utrilla, P., \& Baldellou, V. (2002). Cantos pintados neolíticos de la Cueva de Chaves (Bastarás, Huesca). Salduie, 2, 45-126.

Utrilla, P., \& Baldellou, V. (2007). Les galets peints de la grotte de Chaves (pp. 73-88). Toulouse: Préhistoire, Arts et Societés LXII.

Utrilla, P., \& Laborda, R. (2018). La Cueva de Chaves (Bastarás, Huesca), el gran lugar de habitat del prepirineo: 15000 años de ocupación. Trabajos De Prehistoria, 75, 1-22.

Utrilla, P., Lorenzo, J. I., Baldellou, V., Sopena, M. C., \& Ayuso, P. (2008). Enterramiento masculino en fosa, cubierto de cantos rodados, en el neolítico antiguo de la cueva de Chaves. In M. S. Hernández, J. A. Soler, \& J. A. López (Eds.), IV congreso del neolítico peninsular. Museo arqueológico de alicante (MARQ) (Vol. 2, pp. 131-140), Alicante.

Valentin, J. (2002). Basic anatomical and physiological data for use in radiological protection: Reference values. Annals of the ICRP, 32, 1-185.

Van der Merwe, N. J. (1982). Carbon isotopes, photosynthesis, and archaeology: Different pathways of photosynthesis cause characteristic changes in carbon isotope ratios that make possible the study of prehistoric human diets. American Scientist, 70, 596-606.

Van Klinken, G. J. (1999). Bone collagen quality indicators for palaeodietary and radiocarbon measurements. Journal of Archaeological Science, 26, 687-695.

Villalba-Mouco, V., Sauqué, V., Sarasketa-Gartzia, I., Pastor, M. V., J., Le Roux, P., Vicente, D., Utrilla, P., ... Alazar-García, D. C. (2018). Territorial mobility and subsistence strategies during the Ebro Basin Late Neolithic-Chalcolithic: A multi-isotope approach from San Juan cave (Loarre, Spain). Quaternary International, 481, 28-41.

Villar, L., \& Fernández, J. V. (2000). Usos etnobotánicos de la "Sabina albar" y arbustos que le acompañan en Aragón. ONF Les Dossiers Forestiers, 6, 130-139.

Virgós, E. (2005). Tejón-Meles meles. In: L. M. Carrascal \& A. Salvador (Eds.), Enciclopedia virtual de los vertebrados españoles. Madrid: Museo Nacional de Ciencias Naturales. http://www.vertebradosibericos.org/

Zapata, L., Baldellou, V., \& Utrilla, P. (2008). Bellotas de cronología neolítica para consumo humano en la cueva de Chaves (Bastarás, Huesca). In M. S. Hernández, J. A. Soler, \& J. A. López (Eds.), IV Congreso del neolítico peninsular. Museo arqueológico de alicante (MARQ) (pp. 402-410), Alicante.

Zapata, L., Peña-Chocarro, L., Pérez-Jordá, G., \& Stika, H. P. (2004). Early Neolithic agricultura in the Iberian Peninsula. Journal of World Prehistory, 18, 283-325.

Zeder, M. A. (2008). Domestication and early agriculture in the Mediterranean Basin: Origins, diffusion, and impact. Proceedings of the National Academy of Sciences of the United States of America, 105, 11597-11604.

Zilhão, J. (1992). Gruta do caldeirão O neolitico antigo. Lisbon: Instituto Português do Património Arquitectónico e Arqueológico.

Zilhão, J. (2001). Radiocarbon evidence for maritime pioneer colonization at the origins of farming in west Mediterranean Europe. Proceedings of the National Academy of Sciences of the United States of America, 98, 14180-14185.

How to cite this article: Villalba-Mouco $V$, Utrilla $P$, Laborda R, Lorenzo Jl, Martínez-Labarga C, Salazar-García DC. Reconstruction of human subsistence and husbandry strategies from the Iberian Early Neolithic: A stable isotope approach. Am J Phys Anthropol. 2018;1-15. https://doi.org/10. 1002/ajpa.23622 